\title{
Methane and carbon dioxide emissions from different ecosystems at the end of dry period in South Vietnam
}

\author{
Jiří Dušek $^{1}\left[\right.$ D $\cdot$ Vinh Xuan Nguyen ${ }^{1,2,3,4} \cdot$ Thuyen Xuan Le $^{3} \cdot$ Marian Pavelka $^{1}$
}

Received: 30 June 2020 / Revised: 2 October 2020 / Accepted: 18 October 2020 / Published online: 4 November 2020

(c) The Author(s) 2020

\begin{abstract}
The carbon cycle includes important fluxes of methane $\left(\mathrm{CH}_{4}\right)$ and carbon dioxide $\left(\mathrm{CO}_{2}\right)$ between the ecosystem and the atmosphere. The fluxes may acquire either positive (release) or negative values (consumption). We calculated these fluxes based on short-campaign in situ chamber measurements from four ecosystems of South Vietnam: intact mountain rain forest, rice field, Melaleuca forest and mangroves (different sites with Avicennia or Rhizophora and a typhoon-disturbed gap). Soil measurements were supplemented by chamber measurements of gas fluxes from the tree stems. Measuring $\mathrm{CH}_{4}$ and $\mathrm{CO}_{2}$ together facilitates the assessment of the ratio between these two gases in connection with current conditions and specificity of individual ecosystems. The highest fluxes of $\mathrm{CH}_{4}$ were recorded in the Melaleuca forest, being within the range from 356.7 to $784.2 \mathrm{mg} \mathrm{CH}_{4}-\mathrm{C} \mathrm{m}^{-2}$ day ${ }^{-1}$ accompanied by higher fluxes of $\mathrm{CH}_{4}$ release from Melaleuca tree stems (8.0-262.1 $\mathrm{mg} \mathrm{CH}_{4}-\mathrm{C} \mathrm{m}^{-2}$ day $^{-1}$ ). Significant negative soil fluxes of $\mathrm{CH}_{4}$ were recorded in the mountain rain forest, within the range from -0.3 to $-0.8 \mathrm{mg} \mathrm{CH}_{4}-\mathrm{C} \mathrm{m}^{-2}$ day $^{-1}$. Fluxes of $\mathrm{CO}_{2}$ indicate prevailing aerobic activity in the soils of the ecosystems investigated. Quite a large variability of $\mathrm{CO}_{2}$ fluxes was recorded in the soil of the Avicennia mangroves. The in situ measurements of different ecosystems are fundamental for follow-up measurements at different levels such as aerial and satellite gas fluxes observations.
\end{abstract}

Keywords Avicennia alba $\cdot$ Mangroves $\cdot$ Melaleuca cajuputi $\cdot$ Mountain rain forest $\cdot$ Rhizophora apiculata $\cdot$ Rice field

\section{Introduction}

Functioning of different ecosystems over the landscapes is connected to different dynamics of gas exchange between the atmosphere as the major temporary exchange sink/source of gases, and the whole ecosystem. In carbon cycle, involving biogenic processes, there are important fluxes of methane

Jiří Dušek

dusek.j@czechglobe.cz

1 Global Change Research Institute of the Czech Academy of Sciences, Bělidla 4a, 60300 Brno, Czech Republic

2 Department of Ecology, Institute of Tropical Biology VAST, 85 Tran Quoc Toan Street, District 3, Ho Chi Minh City, Vietnam

3 Research Center for Greenhouse Gas and Climate Change, Ho Chi Minh City University of Science, 227 Nguyen Van $\mathrm{Cu}$ Street, District 5, Ho Chi Minh City, Vietnam

4 Faculty of Forestry and Wood Technology, Mendel University in Brno, Zemědělská 1, 61300 Brno,

Czech Republic
$\left(\mathrm{CH}_{4}\right)$ and carbon dioxide $\left(\mathrm{CO}_{2}\right)$, which may acquire either positive (release) or negative values (oxidation/uptake). These gases together with nitrous oxide $\left(\mathrm{N}_{2} \mathrm{O}\right)$ and water vapour $\left(\mathrm{H}_{2} \mathrm{O}\right)$, belong to greenhouse gases which affect global climate change [World Meteorological Organization (WMO) 2019]. Gradually increasing global concentration of these gases is important in relation to exchange of these gases at ecosystem level. Efflux of $\mathrm{CH}_{4}$ and $\mathrm{CO}_{2}$ is closely related to the functioning of individual ecosystems, especially in their soils. Anaerobic reducing conditions facilitate $\mathrm{CH}_{4}$ production and its subsequent positive fluxes (emissions) from the soils (Mer and Roger 2001; Richardson and Vepraskas 2001). $\mathrm{CH}_{4}$ is produced by different groups of microorganisms in sequence within the anaerobic food chain (Mer and Roger 2001; Wagner 2017). On the other hand, positive fluxes (release) of $\mathrm{CO}_{2}$ are related to prevailing aerobic conditions in the soil profile. In general, $\mathrm{CO}_{2}$ production in soils results from autotrophic respiration of live belowground plant parts (roots and rhizomes) and from heterotrophic respiration, mainly that of microorganisms (Kutsch et al. 2005; Kuzyakov 2006). Fluxes of both gases 
are mostly highly variable both in space and time (Nicolini et al. 2013; Darenova et al. 2016; Acosta et al. 2019). The dynamics of the gas fluxes is connected with highly variable and heterogeneous conditions, which varied from strictly anaerobic to strictly aerobic ones.

Soil heterogeneity can be understood in terms of matter structure, functioning and scale (size), all changing dynamically over time. In tropical ecosystems, potential $\mathrm{CH}_{4}$ and $\mathrm{CO}_{2}$ fluxes occur under favourable conditions, almost without any temperature and/or humidity limitation (Chimner 2004). Final rates of $\mathrm{CH}_{4}$ and $\mathrm{CO}_{2}$ fluxes are usually related to the highest rates of decomposition of organic matter (Segers 1998), resulting in a rapid turnover of organic matter (Wang et al. 2017), connected with gas fluxes from the soil. In tropical peatlands, the measured soil respiration (release of $\mathrm{CO}_{2}$ ) rates can be lower than those measured in temperate and boreal peatlands in summer (Chimner 2004). Tropical peatlands receive a continuous supply of organic carbon throughout the year, which results in more stabilized $\mathrm{CO}_{2}$ fluxes. Typical of tropical soils is also their usually small diurnal dynamics of gas fluxes due to similar soil temperatures during the light and the dark period of the day when the soil moisture does not change (Kursar 1989; Chimner 2004). Very low soil moisture enables increase of the soil temperatures up to $50{ }^{\circ} \mathrm{C}$ mainly in subhumid and semiarid tropical regions (Lal and Sánchez 1992). Dynamics and sensitivity of $\mathrm{CH}_{4}$ and $\mathrm{CO}_{2}$ emissions to changing soil temperature characterized by the temperature coefficient $\left(\mathrm{Q}_{10}\right)$ may be less sensitive to the increase of the soil temperature than a decrease of the soil temperature. The temperature sensitivity $\left(\mathrm{Q}_{10}\right)$ usually was not changed in the tropical soil, if the soil temperature increased but changed if the soil temperature decreased (Bekku et al. 2003). In general, methanogenesis is more temperature sensitive than aerobic respiration (YvonDurocher et al. 2014; Chowdhury et al. 2015) and $\mathrm{CH}_{4}$ fluxes have consistent temperature dependence across scales from cultures of methanogens to ecosystems (Yvon-Durocher et al. 2014).

The knowledge of $\mathrm{CH}_{4}$ and $\mathrm{CO}_{2}$ fluxes from various tropical ecosystems is important to determine the response of carbon cycle to climatic changes. In connection with that, is crucial to keep the ecosystems in a state suitable for their long-term mitigation functioning ongoing climate changes. Overall, one-fifth of anthropogenic greenhouse gas emissions can be sequestered by the terrestrial part of the biosphere. This situation represents a high opportunity for applying an important "natural solution" (e.g., the blue carbon initiative) to climate change (Griscom et al. 2017; Banerjee et al. 2020).

We report here the results of a short-term campaign of in situ measurements of $\mathrm{CH}_{4}$ and $\mathrm{CO}_{2}$ fluxes from the soils (five sites), stagnant shallow water (one site) and measurements of gas fluxes from the tree stems (tree sites) in different ecosystems. Merely short-term campaign measurements were carried out in view of the impossibility to realize long-term in situ measurements. The study sites are lacking an infrastructure that would support long-term measurements with complex scientific equipment.

Although during the last decade increased number of studies from the tropical regions, there are still not enough especially in situ measurements from the tropical wetland ecosystems. The motivation of our measurements was to obtain in situ measured data of $\mathrm{CH}_{4}$ and $\mathrm{CO}_{2}$ fluxes measured at end of the dry (intermediate/transition) period, using the same methods, employing manual soil and treestem emission gas chambers. The results should allow us to make meaningful comparisons of gas fluxes in various ecosystems and also can be used in different approaches using in situ data together with satellite $\mathrm{CH}_{4}$ observations (Bloom et al. 2010; Fraser et al. 2014; Parker et al. 2018). Measuring both gases together enables us to assess the relation (ratio) between them and relations to current conditions and specificity of individual ecosystems. The ratio of $\mathrm{CO}_{2}: \mathrm{CH}_{4}$ itself shows settings of ongoing processes associated with gas fluxes at the soil and ecosystem level (McMillan et al. 2007; Chowdhury et al. 2015).

We try to verify the following hypotheses: (1) high efflux of $\mathrm{CH}_{4}$ occurs mainly in water-saturated soils (mangrove sites and Melaleuca forest) whereas high $\mathrm{CO}_{2}$ efflux occurs in soils of the mountain rain forest. (2) The ratio of $\mathrm{CH}_{4}$ to $\mathrm{CO}_{2}$ emissions will reflect the actual hydrological conditions, especially in the terms of anaerobic versus aerobic conditions. (3) Fluxes of both gases from the tree stems will be related to fluxes from the soil or stagnant water. (4) In forest ecosystems, minor negative fluxes of $\mathrm{CH}_{4}$ take place, thereby indicating consumption (oxidation) of $\mathrm{CH}_{4}$ in the soil or tree stems.

\section{Methods}

\section{Site description}

In situ measurement of gas fluxes was carried out in the Bidoup montane evergreen broadleaved rain forest, Tram Chim National Park, and the Can Gio Mangrove forest, on 29-30 April, 3-4 and 6-7 May 2017, respectively (Fig. 1; Table 1). Soil flux measurements were taken in situations when the water level was close to or below soil surface except situation in rice and mangrove sites where water level was above soil surface.

\section{Mountain rain forest}

The mountain rain forest Bidoup is a montane evergreen broadleaf forest in the Bidoup-Nui Ba National Park, Lam 


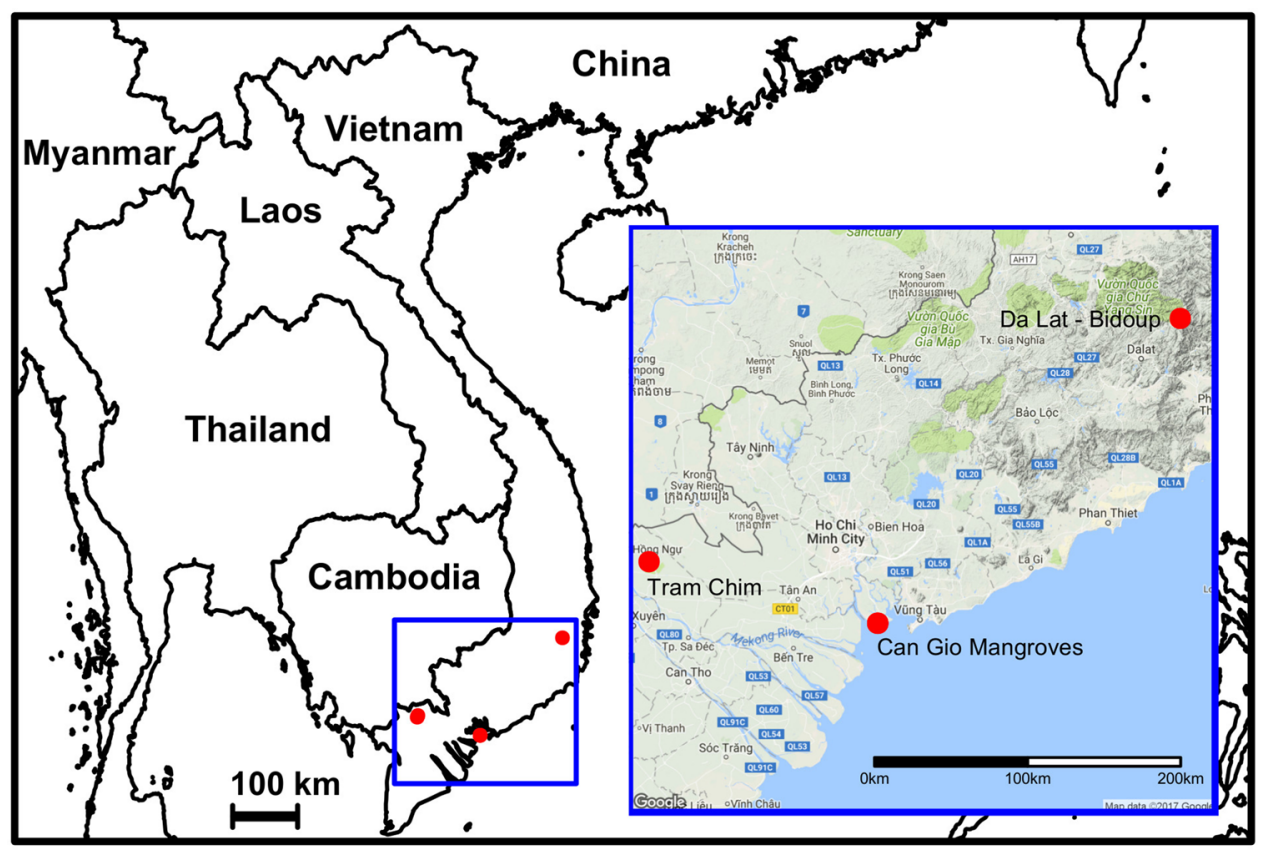

Fig. 1 A map of Southeast Asia and southern part of Vietnam showing the location of sites which host in total 6 studied ecosystems: Da Lat-Bidoup (mountain tropical rain forest), Tram Chim (stagnant shallow water under Melaleuca forest canopy, rice field), Can Gio (Avicennia, Rhizophora and typhoon-disturbed gap). The main and detailed maps was drawn using the $\mathrm{R}$ packages (Chambers 2008) "rworldmap" version 1.3-6 (https://cran.r-project.org/web/packa ges/rworldmap/),"ggplot2" version 3.2.1 (https://cran.r-project.org/ web/packages/ggplot2/) and 'ggmap' version 3.0.0 (https://cran.rproject.org/web/packages/ggmap/). Detailed map of the southern part of Vietnam displayed was queried from the Google Maps (Map data $\odot 2017$ Google) using the function 'get_map' in the 'ggmap' R package

Table 1 Description of the in situ measurement sites in South Vietnam (FAO 1993; Nguyen 2000; Tran and Barzen 2016)

\begin{tabular}{|c|c|c|c|}
\hline Study site & Da Lat-Bidoup & Tram Chim & Can Gio \\
\hline Ecosystem & $\begin{array}{l}\text { Montane evergreen broadleaf rain } \\
\text { forest }\end{array}$ & Lowland freshwater forested swamp & Mangroves \\
\hline Measurement sites & Mountain forest & Melaleuca rice field & $\begin{array}{l}\text { Avicennia, Rhizophora } \\
\text { typhoon-disturbed gap }\end{array}$ \\
\hline Elevation (m) & 1500 & $1-2$ & $1-2$ \\
\hline Climate type & Tropical monsoon in montane area & Tropical monsoon & Tropical monsoon \\
\hline Annual mean air temperature $\left({ }^{\circ} \mathrm{C}\right)$ & 18 & 27 & 27.6 \\
\hline $\begin{array}{l}\text { Annual mean relative air humidity } \\
(\%)\end{array}$ & 85 & 82 & 80 \\
\hline $\begin{array}{l}\text { Mean total annual precipitation } \\
(\mathrm{mm})\end{array}$ & 1857 & 1400 & 1336 \\
\hline $\begin{array}{l}\text { Coordinates of the measurement } \\
\text { sites }\end{array}$ & $12.172624^{\circ} \mathrm{N}, 108.697346^{\circ} \mathrm{E}$ & $\begin{array}{l}10.718262^{\circ} \mathrm{N}, 105.500842^{\circ} \mathrm{E} \\
10.748335^{\circ} \mathrm{N}, 105.515893^{\circ} \mathrm{E}\end{array}$ & $\begin{array}{l}10.385794^{\circ} \mathrm{N}, 106.885788^{\circ} \mathrm{E} \\
10.385703^{\circ} \mathrm{N}, 106.885595^{\circ} \mathrm{E} \\
10.386737^{\circ} \mathrm{N}, 106.885089^{\circ} \mathrm{E}\end{array}$ \\
\hline
\end{tabular}

Dong Province: The measurement site is located on the Langbian Plateau which is a part of the Central Highlands of Vietnam (Fig. 1; Table 1). The forest is dominated by species of the Fagaceae and Lauraceae families, including Castanopsis indica, Lithocarpus spp., Quercus spp., Cinnamomum spp. and Litsea spp., and mixed with coniferous species, such as Pinus dalatensis, Calocedrus macrolepis, Fokienia hodginsii and Podocarpus imbricatus (Tordoff et al. 2004). This forest type represents a pristine natural habitat of the much larger Southern Annamites montane rain forests in Laos and Vietnam (Queiroz et al. 2013). 


\section{Melaleuca forest}

The Tram Chim Melaleuca flooded forest in the Tram Chim National Park, Dong Thap Province of the Mekong Delta (Fig. 1; Table 1). Tram Chim National Park is one of the last remnants of the Plain of Reeds, which was once a vast freshwater floodplain of the Mekong River, covering an area of approximately one million hectares in Cambodia and Vietnam (Tran and Barzen 2016). Efflux gas measurement was carried out in an adult Melaleuca cajuputi forest stand and on its adjacent open water surface (Melaleuca stagnant water). The land inside the Tram Chim National Park had been left inundated $(0.3-0.7 \mathrm{~m})$ by closing all water gates since June 2016 because of concerns about repetition of severe drought like that recorded in 2016.

\section{Rice field}

Efflux gas measurement was carried out one week after rice seeding in the Tram Chim National Park buffer zone experiencing shallow flooding with water $0.03 \mathrm{~m}$ deep (Fig. 1; Table 1).

\section{Avicennia, Rhizophora and typhoon-disturbed gap}

The measurement sites Avicennia, Rhizophora and typhoondisturbed gap include different habitats such as a 30 years old planted Rhizophora apiculata forest stand, natural Avicennia alba stand along a tidal creek and a typhoon-disturbed gap (bare land) with some regenerating mangrove seedlings, where there had also been a planted forest until it was destroyed by the typhoon Durian in December 2006. These habitats are located in the Can Gio Mangrove forest, which is the main part of the Can Gio UNESCO Biosphere Reserve in the coastal zone district of Ho Chi Minh City, a low-lying delta of the Sai Gon-Dong Nai rivers (Fig. 1; Table 1). The Can Gio area once supported natural mangrove forest but almost all of it was destroyed by herbicides during the Second Indochina War (1954-1975). Between 1978 and 1986, the area was reforested with Rhizophora apiculata. The reafforestation effort has been successful in getting the forest cover back and promoting natural regeneration of whole mangrove ecosystems (Tordoff et al. 2004). Current area of mangroves decreased in the south-eastern part of the Mekong River Delta in Vietnam mainly due to expansion of aquaculture farms (Hong et al. 2019).

\section{Soil structure and properties}

The soils were different in the ecosystems studied. Coarse structure was found in the mountain rain forest soil where the percentage content of sand particles was the highest out of all analysed soils (33-37\%) across the soil profile to
0-0.6 m depth. Soils from the other ecosystems contained less than $22 \%$ of sand particles (8.2-21.6\%). The highest percentage content of clay particles was found in the soil of the Rhizophora site (52\%) and in the soil of the rice field $(50.1 \%)$. The percentage content of silt in the soils was within the range of $24.0-49.6 \%$ and complemented that of fine particles, also including clay, which was up to 80-90\%.

Soil acidity, i.e., $\mathrm{pH}\left(\mathrm{H}_{2} \mathrm{O}\right)$, ranged between 4.07 and 5.80 in the soil profiles. The lowest soil $\mathrm{pH}$ was recorded in the rice field and the highest was in the Rhizophora soil profile.

The highest percentage contents of soil organic carbon (about 6\%) were determined in the top layer $(0-5 \mathrm{~cm})$ of the mountain rain forest soil and in the lower layer $(19-60 \mathrm{~cm})$ of the rice-field soil. The lowest organic carbon percentage content $(<2 \%)$ was found in the lower soil layer $(20-60 \mathrm{~cm})$ of the mountain rain forest soil.

The nitrogen percentage content was highest in the topsoil layers of all soil profiles $(0.213-0.536 \%)$. The highest phosphorus percentage content was recorded in the topsoil $(0-19 \mathrm{~cm})$ of the rice field $(0.179 \%)$. The other soil layers contained phosphorus within the range of $0.041-0.072 \%$ except the soil at the typhoon-disturbed gap site, with $0.141 \%$ of phosphorus in the $12-60 \mathrm{~cm}$ soil layer.

Different contents of nitrogen and carbon resulted in different ratios between these two elements (Fig. 2). The lowest carbon to nitrogen ratio $(\mathrm{C}: \mathrm{N})$ was found at the typhoon-gap site where it was about 10 below $0.1 \mathrm{~m}$ depth and 18 in the topsoil. These different C:N ratios are caused by different contents of carbon in different soil layers while nitrogen content was similar in the upper and lower soil layers. The highest C:N ratio (19) was found in the lower soil layers at the Avicennia site. Apparent change of the $\mathrm{C}: \mathrm{N}$ ratio with soil depth was found in the typhoon-disturbed gap profile.

\section{Chamber measurements}

Gas fluxes were measured using two types of chambers designed for soil and tree stem fluxes. The soil gas fluxes were measured at 5, 7 and 10 positions and those in water were at 3 positions from the stagnant water surface, according to the ecosystem investigated. Each soil chamber has a cylindrical shape with $18.9 \mathrm{~cm}$ inner diameter and $3.167 \mathrm{~L}$ volume. At each individual measurement position and 1 day before the measurements, a PVC collar was installed into the soil at about 5-10 $\mathrm{cm}$ depth, depending on current conditions. Stem fluxes (3-5 individual tree stems) were measured in tree-stem chambers of a plastic block shape (plan $0.097 \mathrm{~m}$ $\times 0.065 \mathrm{~m}$ ) and volume of $0.470 \mathrm{~L}$.

One day before the measurements, the stem chambers were fixed to the tree stems at $0.40 \mathrm{~m}$ (mangroves) and $1.10 \mathrm{~m}$ heights (mountain rain forest) with a plastics tape and sealed with silicone. The opening top part of each stem chamber was closed during the measurements by a sealed 


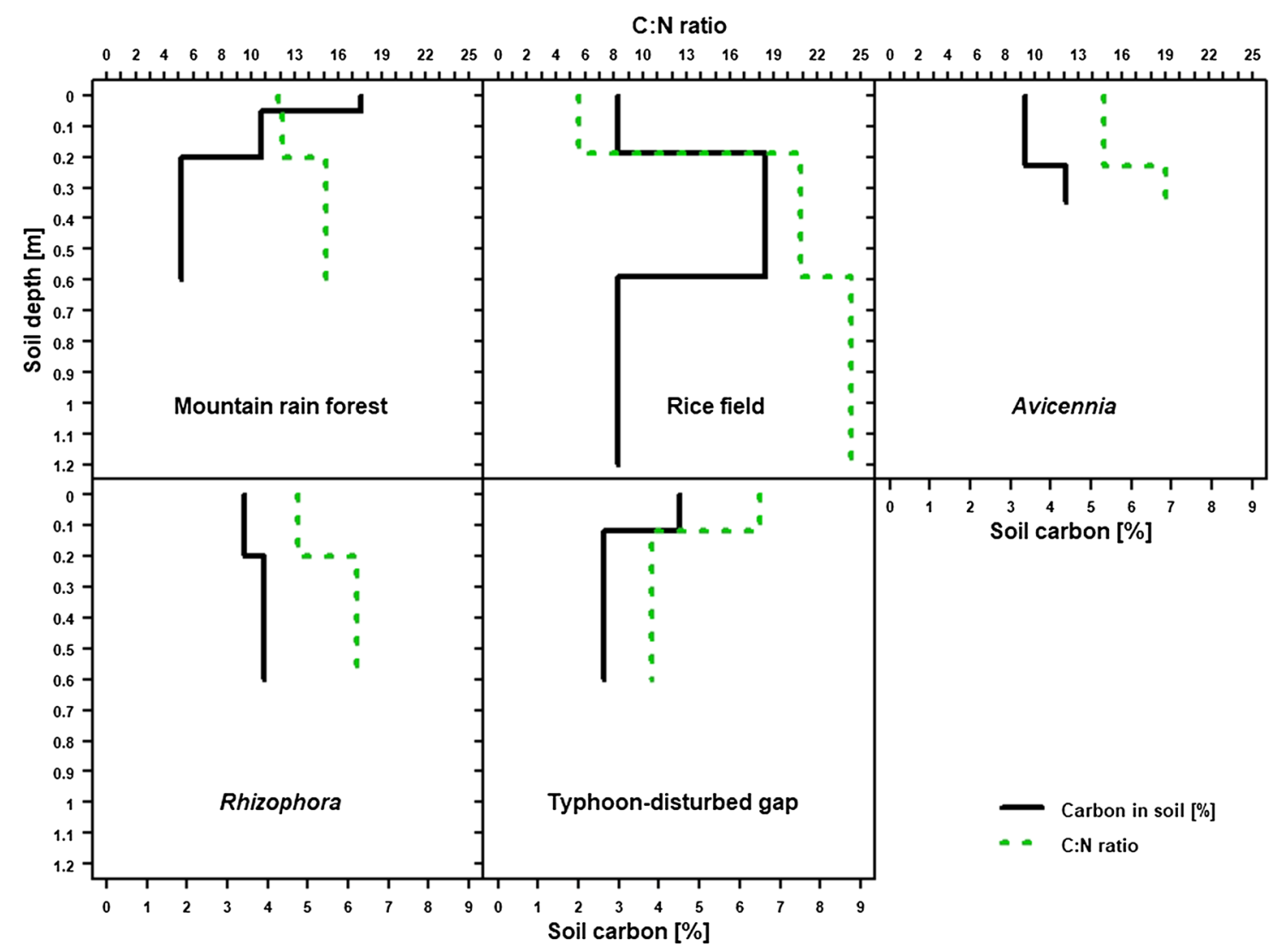

Fig. 2 Distribution of belowground organic carbon percentage content in soil dry mass at the sites studied (Mountaint rain forest, Rice field, Avicennia, Rhizophora and typhoon-disturbed gap sites) except

plastic cover with mechanical locks. Both the soil-chamber and tree-stem chamber measurements were taken during daytime ebb tides, when the ground was only incompletely inundated.

The $\mathrm{CH}_{4}$ and $\mathrm{CO}_{2}$ flux measurements as such were carried out using a non-steady state closed soil/stem chamber system (Matson and Harriss 1995). Changing concentrations of $\mathrm{CH}_{4}$ and $\mathrm{CO}_{2}$ inside the closed chambers were measured at one-second intervals with a fast methane analyser GGA30p (Los Gatos Research Inc., CA, USA). For the subsequent data processing of one-second, the raw data were used with vapour dilution correction (Butenhoff and Khalil 2002).

\section{Redox potential measurements}

Redox potential $\left(\mathrm{E}_{\mathrm{H}}\right)$ was measured using platinum electrodes and a reference electrode $(\mathrm{Ag} / \mathrm{AgCl})$ together with the multimeter Multi340i (WTW, Germany). The electrodes were inserted in the surface soil profile at the depth of about 3-4 cm. The final $E_{H}$ values were corrected relative to the normal $\mathrm{H}$ electrode by adding $+200 \mathrm{mV}$ (van Bochove et al. 2002).
Melaleuca stagnant water site. Full lines-percentage content of organic carbon, dashed green lines- $\mathrm{C}: \mathrm{N}$ ratio

\section{Data processing}

Calculation of the gas fluxes is based on the slope of the linear regression of gas concentration in a chamber's headspace against time (period of 4-5 min), taking into account the chamber volume $(3.167 \mathrm{~L})$ and surface area occupied by the chamber $\left(0.02806 \mathrm{~m}^{2}\right)$. Calculations of the gas fluxes also include their adaptation to the current air temperature and ambient air pressure (Juszczak et al. 2012). The final flux calculation was checked in terms of temporal linearity of gas concentration changes inside a close chamber during the measurements, using the adjusted correlation coefficient $\left(\mathrm{R}^{2}\right)$. Gas fluxes with $\mathrm{R}^{2}>0.80$ are assumed to be correct flux estimates (Juszczak et al. 2012). The calculated fluxes were tested for their normal distribution using the Shapiro-Wilks test (Zar 2010). Homogeneity of the respective variances was tested using the Bartlett test (Zar 2010). The distribution of the primary data differed significantly from normality $(\mathrm{P}<0.01)$ and their variances were not homogeneous according to the Bartlett test $(\mathrm{P}<0.01)$. Based on these facts, the differences between the soil fluxes of $\mathrm{CH}_{4}$ and $\mathrm{CO}_{2}$ measured in different ecosystems were tested using 
the nonparametric Kruskal-Wallis test with the possibility of multiple comparison between groups (Hollander et al. 2014). Statistical analyses were done using the $R$ statistical software (Chambers 2008) version 3.4.2 with the following packages: "pgirmess" (http://cran.r-project.org/web/packa ges/pgirmess/) and "e1071" (https://cran.r-project.org/web/ packages/e1071/). Relationships between the $\mathrm{CO}_{2}$ and $\mathrm{CH}_{4}$ fluxes were evaluated using the Spearman correlation coefficient (Best and Roberts 1975).

\section{Results}

\section{Conditions during gas flux measurements}

Measurements were taken during the transition period between the dry and rainy monsoon seasons. The lowest air and soil temperatures were recorded in the mountain rain forest at the Da Lat-Bidoup site. Average and median values of the air temperatures were very close to each other, being $20.7^{\circ} \mathrm{C}$ and $20.9^{\circ} \mathrm{C}$, respectively. Average and median values of soil temperature were $18.0^{\circ} \mathrm{C}$ and $18.5^{\circ} \mathrm{C}$, respectively (Table 2). In the other ecosystems studied, the average air temperatures were between 29.1 and $31.0{ }^{\circ} \mathrm{C}$. Average soil temperatures were somewhat lower: between 27.9 and $29.6^{\circ} \mathrm{C}$ and were very close to the median values.

The redox potential $\left(\mathrm{E}_{\mathrm{H}}\right)$ measured in the ecosystems investigated, except the mountain rain forest, was mostly negative, an exception being the typhoon-disturbed gap within mangroves (Can Gio site). At this site, average $\mathrm{E}_{\mathrm{H}}$ was positive: $161.8 \mathrm{mV}$ (median $169.0 \mathrm{mV}$ ). In the other ecosystems, $\mathrm{E}_{\mathrm{H}}$ was negative with values as low as about $-527 \mathrm{mV}$ in the Rhizophora mangroves. In the rest of the ecosystems, $\mathrm{E}_{\mathrm{H}}$ was not lower than $-201.6 \mathrm{mV}$ (Avicennia). The least negative $\mathrm{E}_{\mathrm{H}}$ was measured in the rice field (Tram Chim site): $-116.4 \mathrm{mV}$ on average (median $-72.0 \mathrm{mV}$ ).
Water conductivity differed distinctly between the mangrove sites (Avicennia, Rhizophora and typhoon-disturbed gap) and freshwaters ecosystems represented by the rice field and the site with stagnant shallow water below the Melaleuca forest canopy. In the mangroves, the conductivity of interstitial water was within the range of 88.3-112.9 $\mathrm{mS} \mathrm{cm}-1$ (Table 2). The mangrove sites were influenced by both saline sea water and fresh river water creating brackish conditions in the soil. At the site with stagnant shallow water under Melaleuca forest canopy and in the rice field, the water conductivity was significantly lower about $0.633 \mathrm{mS} \mathrm{cm}^{-1}$ and $0.698 \mathrm{mS} \mathrm{cm}^{-1}$ respectively (Table 2). This conductivity characterizes freshwater contained in the respective soils.

\section{Soil methane fluxes}

The recorded $\mathrm{CH}_{4}$ fluxes from soils and stagnant water of different ecosystems varied within a wide range (Fig. 3). In the mountain rain forest (Da Lat-Bidoup site), the $\mathrm{CH}_{4}$ fluxes from the soil were negative, which means consumption (oxidation) of $\mathrm{CH}_{4}$ in the forest soil. The consumption rate of $\mathrm{CH}_{4}$ was from -0.3 to $-0.8 \mathrm{mg} \mathrm{CH}_{4}-\mathrm{C} \mathrm{m}^{-2}$ day $^{-1}$. Here, in comparison with $\mathrm{CH}_{4}$ fluxes recorded at the other measurement sites, the rate of $\mathrm{CH}_{4}$ consumption (negative flux) was 10 times as low as the minimum negative fluxes and 1000 times as low as the maximum positive fluxes. The consumption of $\mathrm{CH}_{4}$ was slightly negatively skewed (skewness $=-0.124$ ).

The highest positive fluxes of $\mathrm{CH}_{4}$ recorded were those from the stagnant shallow water under Melaleuca forest canopy (Tram Chim site). In this case, the range of $\mathrm{CH}_{4}$ emissions was from 356.7 to $784.2 \mathrm{mg} \mathrm{CH}_{4}-\mathrm{C} \mathrm{m}^{-2}$ day $^{-1}$. The mean of recorded $\mathrm{CH}_{4}$ fluxes was higher than their median value, and the distribution of these fluxes was positively skewed (skewness $=0.378$ ). Soil fluxes of $\mathrm{CH}_{4}$ measured in

Table 2 Actual conditions on the sites where the fluxes of $\mathrm{CH}_{4}$ and $\mathrm{CO}_{2}$ were measured

\begin{tabular}{|c|c|c|c|c|c|c|}
\hline \multirow{2}{*}{$\begin{array}{l}\text { Sites } \\
\text { Parameters/ecosys- } \\
\text { tems }\end{array}$} & \multirow{2}{*}{$\frac{\text { Da Lat-Bidoup }}{\begin{array}{l}\text { Mountain rain } \\
\text { forest }\end{array}}$} & \multicolumn{3}{|c|}{ Can Gio (mangroves) } & \multicolumn{2}{|l|}{ Tram Chim } \\
\hline & & Avicennia & Rhizophora & $\begin{array}{l}\text { Typhoon-disturbed } \\
\text { gap }\end{array}$ & Rice field & $\begin{array}{l}\text { Melaleuca stagnant } \\
\text { water }\end{array}$ \\
\hline $\begin{array}{l}\text { Air temperature } \\
\left({ }^{\circ} \mathrm{C}\right)\end{array}$ & $20.7(20.9)$ & $29.9(30.2)$ & $29.4(30.0)$ & $29.9(30.0)$ & $29.1(29.2)$ & $31.0(31.1)$ \\
\hline $\begin{array}{l}\text { Soil temperature } \\
\left({ }^{\circ} \mathrm{C}\right)\end{array}$ & $18.0(18.5)$ & $27.9(28.0)$ & $28.5(28.0)$ & $29.6(29.3)$ & $28.8(28.7)$ & $28.3(28.4)$ \\
\hline $\begin{array}{l}\text { Redox potential } \\
(\mathrm{mV})^{\mathrm{a}}\end{array}$ & not measured & $-201.6(-165.0)$ & $-527.0(-252.0)$ & $161.8(169.0)$ & $-116.4(-72.0)$ & $-152.8(-112.5)$ \\
\hline $\begin{array}{l}\text { Electrical conduc- } \\
\text { tivity } \\
\left(25^{\circ} \mathrm{C} ; \mathrm{mS} \mathrm{cm}^{-1}\right)\end{array}$ & 0.633 & 88.9 & 112.9 & 88.3 & 0.698 & 0.145 \\
\hline
\end{tabular}

The means and medians in brackets are indicated

${ }^{\mathrm{a}}$ The redox potential was corrected relative to the normal $\mathrm{H}$ electrode by adding $+200 \mathrm{mV}$ (van Bochove et al. 2002) 

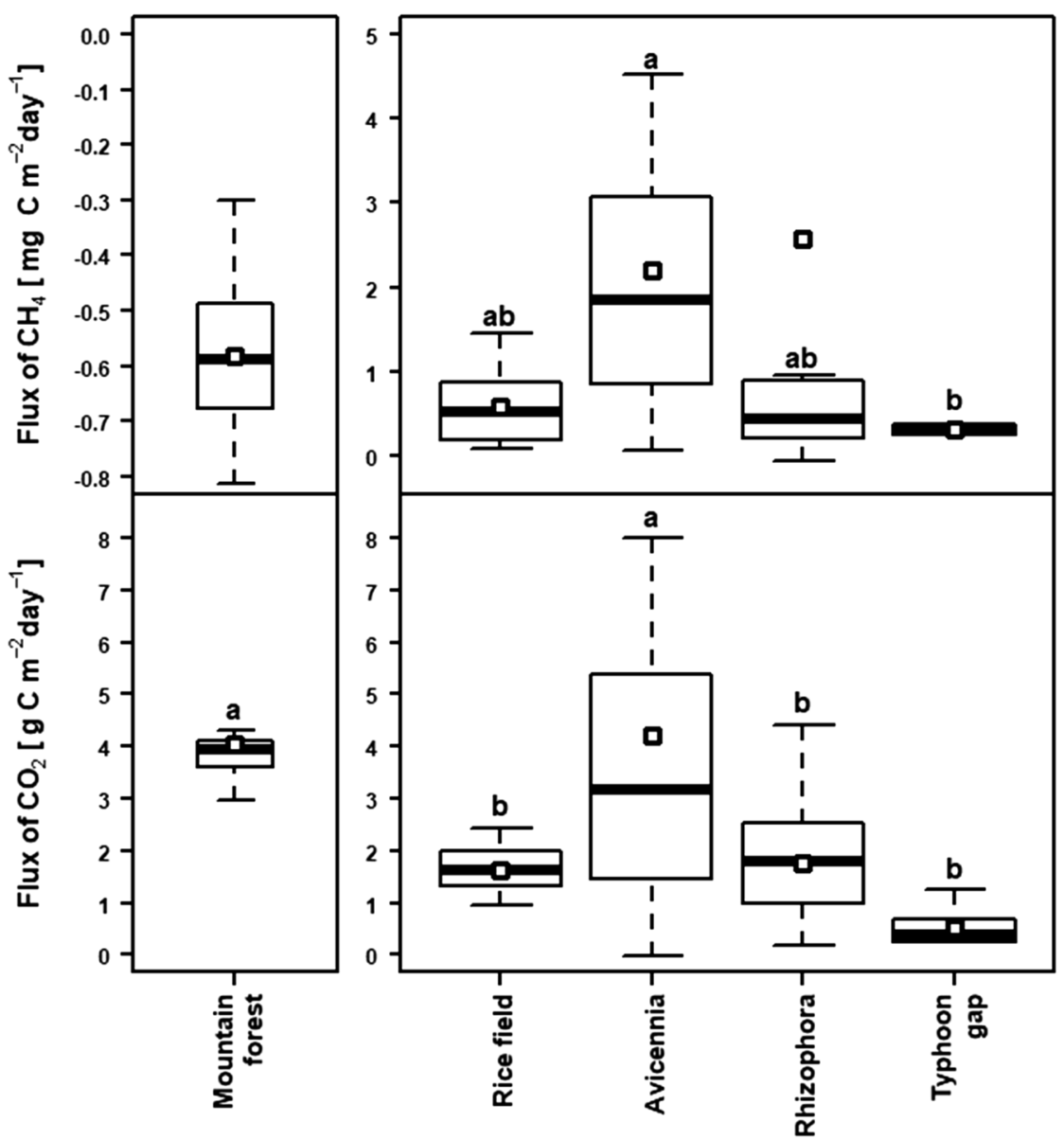

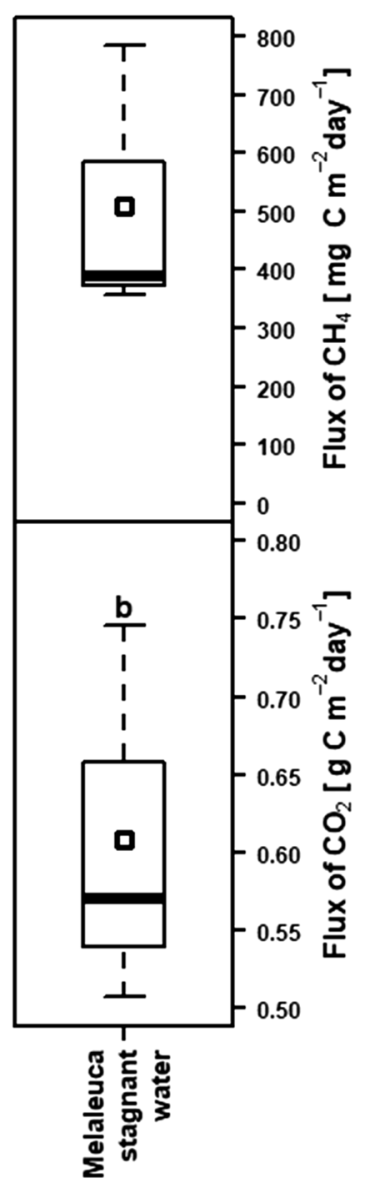

Fig. 3 Fluxes of carbon in the forms of $\mathrm{CH}_{4}$ and $\mathrm{CO}_{2}$ from the soils of different ecosystems and stagnant shallow water under Melaleuca forest canopy. Shown are the means (small open boxes), median values of the second quartile (thick black lines), upper and lower quartile (boxes with 50\% of measured data) and error bars with the upper and lower extreme values indicated. Statistically significant differences between the sites are indicated by different letters the other ecosystems ranged from -0.064 to $7.27 \mathrm{mg} \mathrm{CH}_{4}-\mathrm{C}$ $\mathrm{m}^{-2}$ day $^{-1}$, with almost all the fluxes being positive. Exceptionally weak negative fluxes (consumption of $\mathrm{CH}_{4}$ ) were recorded, on two occasions, in the Rhizophora forest and in the typhoon-disturbed gap (both are mangrove sites). Distributions of these fluxes were almost all positively skewed while they were only slightly negatively skewed $(-0.016)$ in the typhoon-disturbed gap mangrove site.

The widest fluctuation of $\mathrm{CH}_{4}$ fluxes was recorded at the Melaleuca and Avicennia mangrove site, where the fluxes varied between 365.7 and $784.2 \mathrm{mg} \mathrm{CH}_{4}-\mathrm{C} \mathrm{m}^{-2}$ day $^{-1}$ and 0.07 to $7.27 \mathrm{mg} \mathrm{CH}_{4}-\mathrm{C} \mathrm{m}^{-2}$ day $^{-1}$ respectively. These fluxes were positively skewed (skewness $=1.057$ ). Extreme skewness was calculated for fluxes at the Rhizophora mangrove site (skewness $=2.201$ ). This situation shows a significantly shifted mean which was much higher than the median value. At this site, we took several measurements of very high flux rates (up to $19.4 \mathrm{mg} \mathrm{CH}_{4}-\mathrm{C} \mathrm{m}^{-2}$ day $^{-1}$ ). The range of fluxes prevailing at the Rhizophora mangrove site was 0.21 to $0.89 \mathrm{mg} \mathrm{CH}_{4}-\mathrm{C} \mathrm{m}^{-2}$ day $^{-1}$. A very narrow range of $\mathrm{CH}_{4}$ fluxes ( -0.07 to $0.71 \mathrm{mg} \mathrm{CH}_{4}-\mathrm{C} \mathrm{m}^{-2}$ day ${ }^{-1}$ ) was recorded at the typhoon-disturbed gap mangrove site with an only very slightly negative skewness $(-0.016)$, i.e., with an almost unskewed and nearly symmetrical distribution.

Statistical differences among rice field (Tram Chim site), Avicennia, Rhizophora and typhoon-disturbed gap mangrove sites were tested without sites mountain rain forest (Da Lat-Bidoup site) and Melaleuca stagnant water. Separately statistical testing enables to distinguish the differences among the selected sites. Statistically significant differences were found only between the typhoon-disturbed gap mangrove and Avicennia soils (Chisquare $=10.65 ; \mathrm{df}=3 ; \mathrm{P}$ value $=0.01$, Fig. 3 ). Soil fluxes of $\mathrm{CH}_{4}$ at the Avicennia mangrove site were not significantly different from those recorded in the rice field and Rhizophora mangrove site. 


\section{Soil carbon dioxide fluxes}

The $\mathrm{CO}_{2}$ fluxes from the soils recorded in the investigated ecosystems and stagnant shallow water under Melaleuca forest canopy were positive except only one negative value close to zero, recorded at the Avicennia mangrove site when the water level was $2.5 \mathrm{~cm}$ above soil surface. The overall range of $\mathrm{CO}_{2}$ fluxes measured at all the sites was -0.016 to $16.529 \mathrm{~g} \mathrm{CO}_{2}-\mathrm{C} \mathrm{m}^{-2} \mathrm{day}^{-1}$. At the Avicennia mangrove site, the $\mathrm{CO}_{2}$ fluxes fluctuated more widely than at the other measurement sites (Fig. 3). For example, a very narrow range of $\mathrm{CO}_{2}$ fluxes was recorded in stagnant water of the Melaleuca forest (Tram Chim site), namely from 0.51 to $0.75 \mathrm{~g} \mathrm{CO}_{2}-\mathrm{C} \mathrm{m}^{-2} \mathrm{day}^{-1}$. A few higher flux rates were recorded in the typhoon gap of the mangrove site, their range being from 0.24 to $1.24 \mathrm{~g} \mathrm{CO}_{2}-\mathrm{C} \mathrm{m}^{-2}$ day $^{-1}$. Faster fluxes were recorded in the rice field (Tram Chim site), within the range of 0.94 to $2.43 \mathrm{~g} \mathrm{CO}_{2}-\mathrm{C} \mathrm{m}^{-2} \mathrm{day}^{-1}$. Fluxes from the sites rice field, Rhizophora, typhoon gap in mangroves and stagnant water of Melaleuca forest were similar and statistically significantly different from fluxes assessed at the mountain rain forest (Da Lat-Bidoup site) and Avicennia mangrove sites (Chi-squared $=45.76 ; \mathrm{df}=5 ; \mathrm{P}$ value $<0.01$ ). Almost all distributions of $\mathrm{CO}_{2}$ fluxes were skewed positively. This is evident from the shift of the means to higher values, mainly in fluxes from the Avicennia site with the highest skewness (1.567). In this case, we recorded quite high $\mathrm{CO}_{2}$ fluxes of 8.01 and $16.529 \mathrm{~g} \mathrm{CO}_{2}-\mathrm{C} \mathrm{m}^{-2}$ day $^{-1}$ as the maximum values. Other positively skewed fluxes of $\mathrm{CO}_{2}$ were recorded in the mountain rain forest (skewness $=1.262$ ). The rest of the measured fluxes had skewness values below 1 . Namely the distributions of $\mathrm{CO}_{2}$ fluxes from the rice field were very close to symmetrical distribution (skewness $=0.037$ ). The skewness of the remaining fluxes was $0.519,0.911$ and 0.277 for the Rhizophora, typhoon gap in mangroves and stagnant water of the Melaleuca site, respectively.

\section{Relationship between $\mathrm{CH}_{4}$ and $\mathrm{CO}_{2}$ soil fluxes}

Relationship between the fluxes of carbon in the forms of $\mathrm{CO}_{2}$ and $\mathrm{CH}_{4}$ presented as medians shows that the ratio between the two gases broadly varied across the ecosystems. An analysis of the recorded data shows that no clearly visible relationship exists between the $\mathrm{CO}_{2}$ and $\mathrm{CH}_{4}$ fluxes recorded in different ecosystems. Very similar ratios between both gases were recorded at the rice field and the Rhizophora sites (Fig. 4).

Fluxes of $\mathrm{CO}_{2}$ were slightly higher but statistically insignificant at the Rhizophora mangrove site than in the rice field and vice versa: $\mathrm{CH}_{4}$ fluxes were slightly higher but statistically insignificant in the rice field than in Rhizophora. Measurements of $\mathrm{CH}_{4}$ fluxes from these sites were similar also to those from the typhoon-disturbed gap in mangroves site, but under very low $\mathrm{CO}_{2}$ fluxes. The highest $\mathrm{CO}_{2}$ flux rate was recorded along with negative $\mathrm{CH}_{4}$ fluxes (consumption) only in the soil of the mountain rain forest (Da Lat-Bidoup site). High $\mathrm{CO}_{2}$ fluxes were recorded at the Avicennia mangrove site, but along with quite high fluxes of $\mathrm{CH}_{4}$. The highest $\mathrm{CH}_{4}$ fluxes together with low $\mathrm{CO}_{2}$ fluxes were recorded in open water of the Melaleuca forest.

The correlations between the fluxes of $\mathrm{CO}_{2}$ and $\mathrm{CH}_{4}$ analyzed individually for each site was statistically almost non-significant, but for two exceptions: the Avicennia and Rhizophora mangrove sites. In these two cases, the two fluxes were mutually positively correlated. The highest positive correlation was found at the Avicennia mangrove site $\left(\mathrm{R}_{\text {Sperman's }}=0.896, \mathrm{P}\right.$ value $\left.<0.001\right)$. A weaker statistically significant correlation was found at the Rhizophora mangrove site $\left(\mathrm{R}_{\text {Sperman's }}=0.732, \mathrm{P}\right.$ value $\left.<0.01\right)$.

At both sites, we recorded relevant clear signs of $\mathrm{CO}_{2}$ fluxes together with fluxes of $\mathrm{CH}_{4}$. The relationship between $\mathrm{CO}_{2}$ and $\mathrm{CH}_{4}$ fluxes can be easily characterized by statistically significant slopes of a simple linear model without intercept. The calculated slopes were 0.484 ( $\mathrm{P}$ value $<0.001$ ) and 0.785 (P value <0.05) for the Avicennia and Rhizophora mangrove sites, respectively. Higher value of slope in the case of Rhizophora relates to a narrow range of fluxes of both gases recorded there, in comparison with their more variable fluxes recorded at the Avicennia mangrove site.

\section{Fluxes of $\mathrm{CH}_{4}$ and $\mathrm{CO}_{2}$ from tree stems}

Fluxes of $\mathrm{CH}_{4}$ and $\mathrm{CO}_{2}$ were measured individually on the tree stems of different dominant tree plant species: Avicennia alba, Rhizophora apiculata, Melaleuca cajuputi and mountain rain forest trees (Manglietia chevalierii and Castanopsis ceratacantha). Estimated age of these trees was more than 20-30 years. The breast diameters were $0.40 \mathrm{~m}$ and $0.56 \mathrm{~m}$ for Avicennia alba and Rhizophora apiculata, respectively. The measured tree of Melaleuca cajuputi had the breast diameter of $0.20 \mathrm{~m}$ and the trees measured in the mountain rain forest had the breast diameter of $0.30 \mathrm{~m}$. The recorded fluxes of both gases varied quite broadly (Fig. 5). The highest fluxes of $\mathrm{CH}_{4}$ were recorded for the stems of Melaleuca cajuputi (Melaleuca forest site). Positive fluxes were characterized by minimum and maximum values of 8.01 and $262.1 \mathrm{mg} \mathrm{CH}_{4}-\mathrm{C} \mathrm{m}^{-2}$ day $^{-1}$, respectively. The distribution of these fluxes was positively skewed (skewness $=1.335$ ) and their median (37.5 $\mathrm{mg} \mathrm{CH}_{4}-\mathrm{C} \mathrm{m}^{-2}$ day $^{-1}$ ) markedly differed from their mean value $\left(69.8 \mathrm{mg} \mathrm{CH}_{4}-\mathrm{C} \mathrm{m}^{-2}\right.$ day $\left.^{-1}\right)$. High $\mathrm{CH}_{4}$ fluxes from the stems of Melaleuca are followed by the fluxes from the stems of both Avicennia alba (Avicennia site) and Rhizophora apiculata (Rhizophora site). The Avicennia albastems released more $\mathrm{CH}_{4}$ than those of Rhizophora apiculata. The range of these fluxes was from 


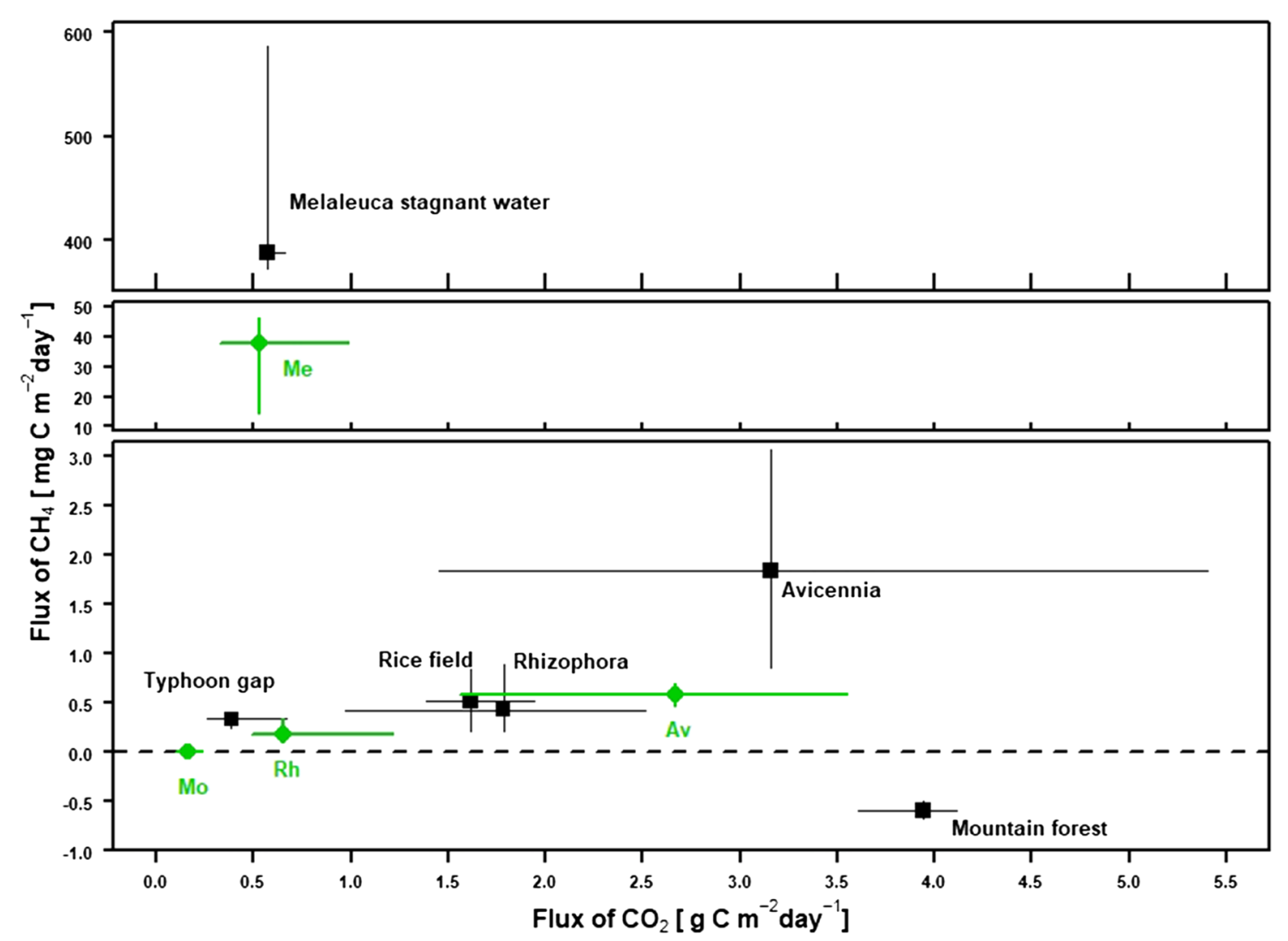

Fig. 4 Relations between fluxes in the form of $\mathrm{CO}_{2}$ and $\mathrm{CH}_{4}$ from soil surface, stagnant shallow water under Melalueca canopy and tree stems (green points) $\mathrm{Me}=$ Melaleuca cajuputi, Av =Avicennia alba, $\mathrm{Rh}=$ Rhizophora apiculata, $\mathrm{Mo}=$ Manglietia chevalierii and Castan-

0.25 to $1.16 \mathrm{mg} \mathrm{CH}_{4}-\mathrm{C} \mathrm{m}^{-2}$ day $^{-1}$ and their distribution was positively skewed (skewness $=0.633$ ). More positively skewed distribution of $\mathrm{CH}_{4}$ fluxes was recorded for the Rhizophora apiculata stems (skewness $=1.484$ ). This skewness was most positive of all distributions of the measured fluxes. The range of the recorded $\mathrm{CH}_{4}$ fluxes was $0.041-0.900 \mathrm{mg}$ $\mathrm{CH}_{4}-\mathrm{C} \mathrm{m}^{-2} \mathrm{day}^{-1}$. The lowest skewness (0.538) was calculated for measurements in the mountain rain forest. The range of the gas-flux measurements as such recorded in the mountain rain forest was very narrow and their median and mean values were 0.090 and $0.165 \mathrm{mg} \mathrm{CH}_{4}-\mathrm{C} \mathrm{m}^{-2} \mathrm{day}^{-1}$, respectively. Statistically significantly differing fluxes from the stems were found in the mountain rain forest as compared with the Avicennia mangrove and Melaleuca forest sites. Stem fluxes measured at the Rhizophora site were similar to those recorded at the Avicennia and mountain rain forest sites. Fluxes of $\mathrm{CH}_{4}$ measured at the Melaleuca site were similar to those at the Avicennia site. This similarity was, however, close to a statistically significant difference according to the Kruskal Wallis test (observed difference $=15.00$ versus critical difference $=15.19$ on the 0.05 probability level). opsis ceratacantha. Medians (black boxes and green circles) and the ranges of the first and the third quartiles are presented, respectively, as vertical and horizontal lines across the medians (color figure online)

Fluxes of $\mathrm{CO}_{2}$ varied from close to zero to $5.06 \mathrm{~g} \mathrm{CO}_{2}-\mathrm{C}$ $\mathrm{m}^{-2}$ day $^{-1}$. The highest fluxes were recorded from the tree stems of Avicennia alba, within the range from 0.90 to $5.06 \mathrm{~g} \mathrm{CO}_{2}-\mathrm{C} \mathrm{m}^{-2} \mathrm{day}^{-1}$. The distribution of these fluxes was slightly positively skewed (skewness $=0.205$ ). The lowest $\mathrm{CO}_{2}$ fluxes, calculated from two measurements, resulted in assessment of negative fluxes from the stems of trees (Manglietia chevalierii and Castanopsis ceratacantha) in the mountain rain forest, where their range was -0.13 to $0.33 \mathrm{~g} \mathrm{CO}_{2}-\mathrm{C} \mathrm{m}^{-2} \mathrm{day}^{-1}$. The distribution of these fluxes was negatively skewed (skewness $=-0.445$ ) and the calculated mean flux $\left(0.14 \mathrm{~g} \mathrm{CO}_{2}-\mathrm{C} \mathrm{m}^{-2} \mathrm{day}^{-1}\right)$ was lower than the median flux value $\left(0.16 \mathrm{~g} \mathrm{CO}_{2}-\mathrm{C} \mathrm{m}^{-2} \mathrm{day}^{-1}\right)$. Similar fluxes of $\mathrm{CO}_{2}$ were measured from the stems of Rhizophora apiculata and Melaleuca cajuputi. This similarity was statistically significant. The distributions of both fluxes were positively skewed but the distribution of data on fluxes from the stems of Melaleuca cajuputi was very positively asymmetric (skewness $=1.165$ ). The median value of these fluxes was distinctly lower $\left(0.53 \mathrm{~g} \mathrm{CO}_{2}-\mathrm{C} \mathrm{m}^{-2} \mathrm{day}^{-1}\right)$ than their mean value $\left(1.04 \mathrm{~g} \mathrm{CO}_{2}-\mathrm{C} \mathrm{m}^{-2} \mathrm{day}^{-1}\right)$. Statistically significant differences were found between Avicennia alba stems 


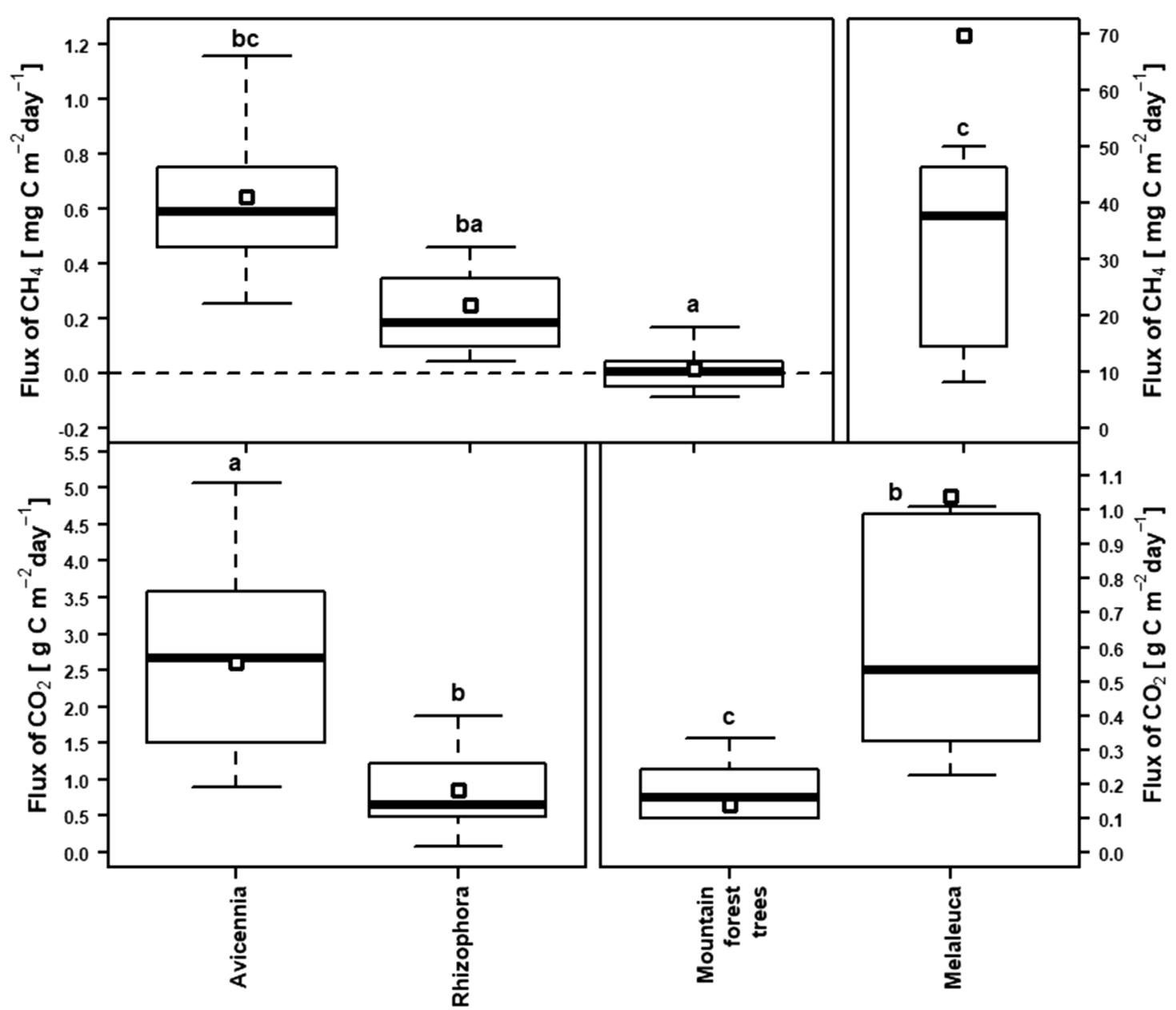

Fig. 5 Fluxes of carbon in $\mathrm{CH}_{4}$ and $\mathrm{CO}_{2}$ forms from the stems of different tree species. Mountain rain forest $=$ (Manglietia chevalierii, Castanopsis ceratacantha), Avicennia =Avicennia alba, Rhizophora $=$ Rhizophora apiculata, Melaleuca $=$ Melaleuca cajuputi . Means (open small boxes), medians of the second quartile (thick

and the rest of the measured stems of different trees (Fig. 5). The fluxes measured from the stems of Melaleuca cajuputi also differed from fluxes from the stems of the mountain rain forest tree species and from those of Avicennia alba (Mangrove).

\section{Comparison of gas fluxes from the soils, stagnant water and tree stems}

In most cases, the fluxes of $\mathrm{CH}_{4}$ and $\mathrm{CO}_{2}$ were higher from the soils and stagnant water, except for only one case in the mountain rain forest where negative flux (consumption) of $\mathrm{CH}_{4}$ was recorded (Fig. 6). Median flux of $\mathrm{CH}_{4}$ from the tree stems was positive and very close to zero $\left(0.003 \mathrm{mg} \mathrm{CH}_{4}-\mathrm{C}\right.$ $\mathrm{m}^{-2}$ day $\left.^{-1}\right)$. Although the gas fluxes were higher from the soils and from shallow stagnant water (Melaleuca site), we found statistically significant differences only in some cases. black lines), upper and lower quartile (boxes with $50 \%$ of measured data) and error bars with upper and lower extreme values are shown. Statistically significant differences between the sites are marked by different letters

Most of the $\mathrm{CH}_{4}$ fluxes were statistically significantly ( $\mathrm{P}$ value $<0.01)$ higher from the soils and stagnant water (Melaleuca site), for the Rhizophora site where the difference was non-significant ( $\mathrm{P}$ value $>0.05$ ). The greatest difference was found for the stagnant shallow water at the Melaleuca site, where the final difference between the median and mean values was between 387.4 and $509.4 \mathrm{mg} \mathrm{CH}_{4}-\mathrm{C} \mathrm{m}^{-2}$ day $^{-1}$, respectively. The $\mathrm{CO}_{2}$ fluxes differed less, and we found two statistically non-significant differences at the Avicennia ( $\mathrm{P}$ value $=0.07)$ and Melaleuca sites $(\mathrm{P}$ value $=0.86)$. At the Melaleuca site, the $\mathrm{CO}_{2}$ fluxes were similarly the lowest among the measurement sites, together with the measurements of fluxes from tree stems in the mountain rain forest (Fig. 6). Statistically significant differences between fluxes from the soils and those from the tree stems were found in Rhizophora and at the mountain rain forest sites. In this forest, the difference between medians and averages was 


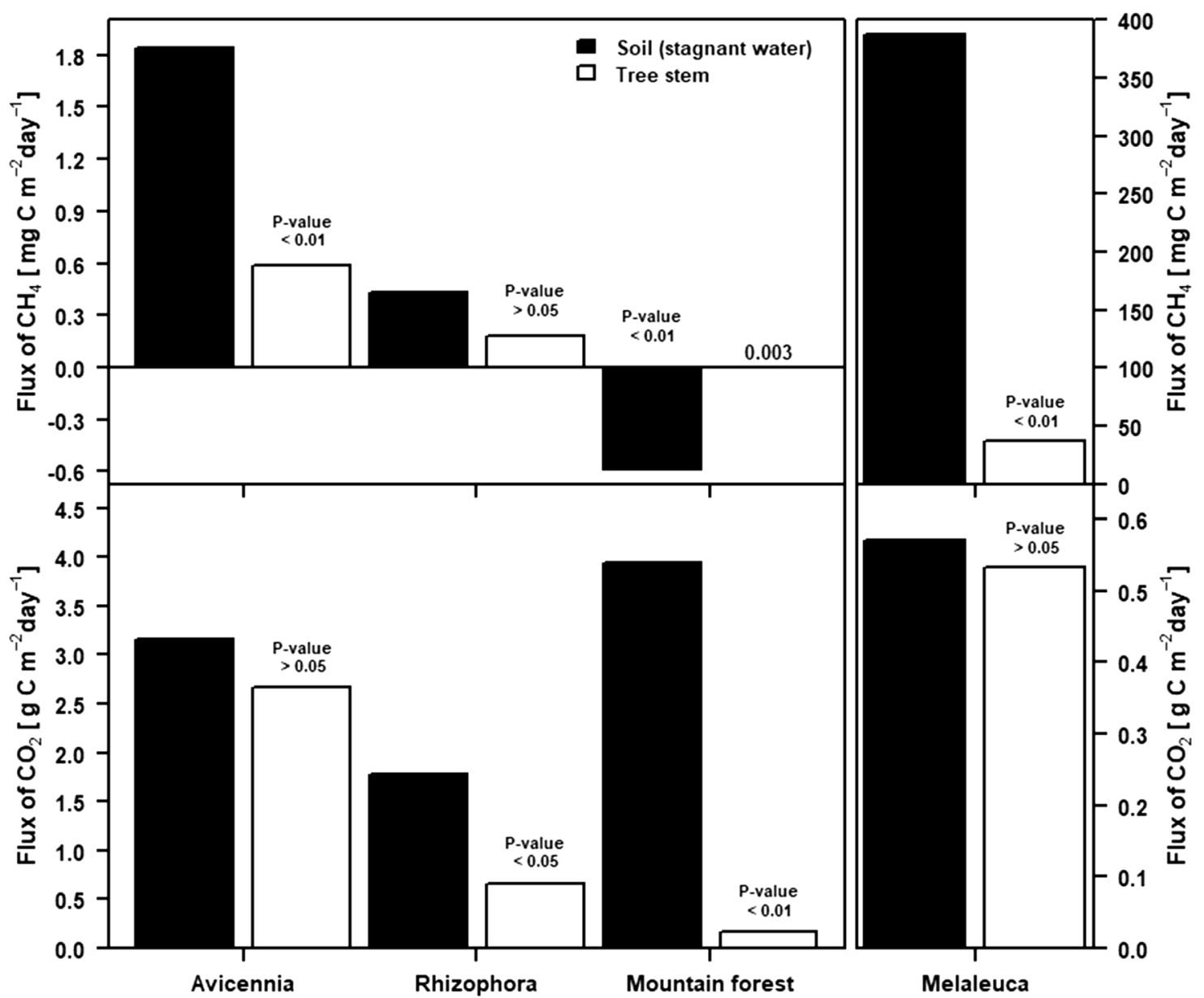

Fig. 6 Comparison of carbon fluxes in $\mathrm{CH}_{4}$ and $\mathrm{CO}_{2}$ forms (medians are presented) from the soils and stagnant shallow water under Melaleuca forest canopy (black boxes) with the same fluxes from stems of different species of trees (white boxes). Rain mountain forest $=$ soil and Manglietia chevalierii, Castanopsis ceratacantha tree stems;

the highest (difference 3.78 and $3.91 \mathrm{~g} \mathrm{CO}_{2}-\mathrm{C} \mathrm{m}^{-2}$ day $^{-1}$, respectively) among the measurement sites. General view of the context of $\mathrm{CH}_{4}$ and $\mathrm{CO}_{2}$ fluxes from the soils and the tree stems is summarized in Fig. 4. It is evident from the graph that wetland plants (trees in our case) show quite high fluctuations in releasing $\mathrm{CH}_{4}$ if this gas is formed in the soil. Fluxes of $\mathrm{CO}_{2}$ fluctuated less widely in comparison with $\mathrm{CH}_{4}$ fluxes and the widest fluctuation was recorded in Melaleuca cajuputi tree stems. In this case, the median soil fluxes and tree-stems fluxes of $\mathrm{CO}_{2}$ were very similar.

\section{Discussion}

Rates and dynamics of soil $\mathrm{CH}_{4}$ and $\mathrm{CO}_{2}$ fluxes usually depend also on the soil type, stand composition, and both current and long-term conditions in the soil profile (Munevar and Wollum 1977; Xu et al. 2004; Lopes de Gerenyu
Avicennia $=$ soil and Avicennia albatree stems;Rhizophora $=$ soil and Rhizophora apiculata tree stems; Melaleuca=soil and Melaleuca cajuputi tree stems. Statistically significant differences between the stem and soil fluxes are indicated by the $\mathrm{P}$ value level

et al. 2015; Ben-Noah and Friedman 2018). Prevailing soil conditions (e.g., aeration, moisture content, amount of soil organic matter and availability of nutrients) determine carbon $\left(\mathrm{CO}_{2}\right)$ balance of a whole ecosystem (Luyssaert et al. 2007) and thereby also long-term carbon pools stored as soil organic matter (SOM) (Post et al. 1982). The mountain rain forest site (Da Lat-Bidoup) belongs to ecosystems with quite a low content of SOM mainly in deeper soil layers. The SOM content decreased rapidly below the depth of $5 \mathrm{~cm}$, despite a relatively high SOM content in the near-surface soil layer. SOM is a complex of organic compounds serving as respiratory substrate which is "aerobically breathed", i.e., decomposed first to simpler compounds and eventually mostly to the final $\mathrm{CO}_{2}$. Low content of SOM in the soil of the mountain rain forest probably reflects an intensive SOM turnover by microbial activity (Wang et al. 2017). The SOM is mineralized also by soil fauna activities, because termite mounds are common around the Da Lat-Bidoup and Cat 
Tien National Park (Lopes de Gerenyu et al. 2015). $\mathrm{CO}_{2}$ fluxes measured in Da Lat-Bidoup tropical mountain rain forest correspond with in situ measurements from other forests with tropical or subtropical climate (Inubushi et al. 2003; Melling et al. 2005; Shvaleva et al. 2011) and also with measurements from forests growing under cooler climatic conditions (Bond-Lamberty and Thomson 2010).

Soil fluxes of $\mathrm{CO}_{2}$ demonstrate an intense oxidation of $\mathrm{SOM}$ under aerobic conditions while those of $\mathrm{CH}_{4}$ demonstrate "anaerobically breathed" SOM, i.e., partly decomposed under anaerobic conditions usually detected in watersaturated soils (Richardson and Vepraskas 2001; Mer and Roger 2001). $\mathrm{CH}_{4}$ fluxes from the mountain rain forest soil were significantly negative (Fig. 3). Negative flux of $\mathrm{CH}_{4}$ means consumption of atmospheric $\mathrm{CH}_{4}$ by the forest soil. The rate of $\mathrm{CH}_{4}$ consumption by the mountain rain forest soil recorded at the Da Lat-Bidoup site is similar to rates measured in situ in tropical forests (Ishizuka et al. 2002; Butterbach-Bahl et al. 2004; Itoh et al. 2012) and also under different climatic conditions, e.g., temperate ones (Crill 1991; Castro et al. 1995; Chan et al. 2005; Dušek et al. 2018). The $\mathrm{CH}_{4}$ consumption is also in agreement with the soil methanotrophy model MeMo v1.0 (Murguia-Flores et al. 2018). Distinctive consumption of $\mathrm{CH}_{4}$ (negative fluxes) was not recorded at the other sites included in this study.

The highest positive fluxes of $\mathrm{CH}_{4}$ were recorded in stagnant shallow water under Melaleuca forest canopy in the Tram Chim National Park. The free water surface released 100 times more $\mathrm{CH}_{4}$ in comparison with the other mangrove forest sites. The Melaleuca forest site is flooded and the level of flooding is artificially maintained by the National park management. The resulting conditions were stable at least for two years and have induced strictly anaerobic reduced conditions facilitating $\mathrm{CH}_{4}$ production (Mer and Roger 2001) in the flooded soil profile. The dominant tree Melaleuca cajuputi is a flooding-tolerant amphibious species (Yamanoshita et al. 2001) whose seedlings can grow under submergence for a long time (Tanaka et al. 2011).

During our measurements in Melaleuca forest site we never saw bubbles rising up from the bottom soil through the water. But during manipulation with a chamber outside of the measurement sites, we recorded some gas bubbles moving upwards from the bottom soil. Ebullition of $\mathrm{CH}_{4}$ is often recorded, mainly in wetlands with free water surface (Strack and Waddington 2008) or in rice paddies (Green 2013). Our measurements were conducted at a stable water level and stable hydrostatic and air pressures. Under these conditions, ebullition was usually a non-significant component of $\mathrm{CH}_{4}$ fluxes (Matson and Harriss 1995). Importance of the ebullition for $\mathrm{CH}_{4}$ fluxes usually increases if the water level significantly fluctuates [e.g., in the Amazon River floodplain (Bartlett et al. 1990)]. $\mathrm{CH}_{4}$ released in bubbles from the bottom soil is only incompletely oxidized while passing through the water column $(0.5 \mathrm{~m})$ and the majority of $\mathrm{CH}_{4}$ in bubbles is emitted from the water surface to the atmosphere.

High fluxes of $\mathrm{CH}_{4}$ from free water surface in the Melaleuca forest connect with high fluxes of $\mathrm{CH}_{4}$ from the stems of adult Melaleuca cajuputi trees. The root system of Melaleuca trees takes up $\mathrm{CH}_{4}$ partially together with water (Reay et al. 2010), or $\mathrm{CH}_{4}$ can penetrate into the trees via their gaspermeable aerenchyma tissues (Colmer 2003). $\mathrm{CH}_{4}$ taken up by roots escapes from the tree mainly via the stems or other aboveground tree parts (branches, leaves). Tree stems are connected to the ambient atmosphere, where the background $\mathrm{CH}_{4}$ concentration is usually less than $2 \mathrm{ppm}$ (1.869 ppm on a global average, WMO Greenhouse Gas Bulletin 2019). But the $\mathrm{CH}_{4}$ concentration inside plant's aerenchyma tissues can be temporarily higher due to increase of concentration during dark (night) period when the aerenchyma tissues is poorly ventilated (Dušek et al. unpublished data). The gradient of $\mathrm{CH}_{4}$ concentration between the atmosphere and tree tissues resulted in positive fluxes of $\mathrm{CH}_{4}$ out from the tree stems to the atmosphere. These tree-stem fluxes of $\mathrm{CH}_{4}$ represent the largest non-ebullitive fluxes from wetlands (Pangala et al. 2017). Fluxes of $\mathrm{CH}_{4}$ from the tree stems are part of the gas exchange system of a whole tree, including the fluxes of $\mathrm{CO}_{2}, \mathrm{~N}_{2} \mathrm{O}$ and biogenic volatile organic compounds (Guenther et al. 1994; Kuhn et al. 2004; Bao et al. 2008). Large emissions from Amazon floodplain trees are close to the $\mathrm{CH}_{4}$ budget of this ecosystem (Pangala et al. 2017). Fluxes of $\mathrm{CO}_{2}$ from the tree stems of Melaleuca cajuputi were variable and low, similar to tree stems fluxes in the mountain rain forest (Castanopsis ceratacantha and Maglietia chevalierii trees). Low tree-stem fluxes of $\mathrm{CO}_{2}$ and variable positive/negative fluxes of $\mathrm{CH}_{4}$ relate to the mountain rain forest as an intact broad-leaved forest in which the age of some trees is hundreds of years. Large gas fluxes from stems of the lowland wetland trees, with $\mathrm{CH}_{4}$ as an important component, were observed among the measured trees: Melaleuca, Rhizophora and Avicennia. Apparently, the flood-tolerant amphibious trees show significantly different pair comparisons of gas fluxes from tree stems and soil respiration (distance between tree species-green circles, and corresponding soil-dark squares in Fig. 4). This fact and a record of relatively widely fluctuating $\mathrm{CH}_{4}$ flux (Fig. 5) reflect the different capability of internal conductive systems of those tree species to facilitate upward escape of soil $\mathrm{CH}_{4}$ to the atmosphere. Furthermore, this response of trees to hydroperiods with upward escape of $\mathrm{CH}_{4}$ is probably an inherited trait of floodplain trees, as it was repeatedly observed in the Borneo wetlands and Amazon basin (Pangala et al. 2017).

Lower and more variable $\mathrm{CH}_{4}$ fluxes from the soil than those from shallow stagnant water under the Melaleuca forest canopy were measured in the mangrove forest, especially at the Avicennia site (stand of Avicennia alba). At the other 
mangrove sites (Rhizophora and typhoon gap), the soil $\mathrm{CH}_{4}$ fluxes were less variable and lower. Fluxes of $\mathrm{CH}_{4}$ from the soil below Rhizophora trees were similar to soil $\mathrm{CH}_{4}$ fluxes measured at the rice field site. These dynamics of $\mathrm{CH}_{4}$ fluxes from the mangrove sites probably relate to regular semidiurnal tidal inundation.

The Avicennia site is located close to a tidal creek that supports water exchange during flood periods that last longer than those occurring at the distant Rhizophora and typhoon gap sites. At the Avicennia site, the carbon fluxes in both forms $\left(\mathrm{CO}_{2}\right.$ and $\left.\mathrm{CH}_{4}\right)$ fluctuated within a wider range than those recorded at the Rhizophora and typhoon gap sites. A recent study (Diele et al. 2013) taken at another place in the Can Gio mangrove demonstrated that the values of redox potential along the soil profile below the Avicennia canopy was relatively higher than that below the Rhizophora canopy. Less negative Eh values along the soil profile recorded at the Avicennia site are most probably caused by the occurrence of pneumatophores, which facilitate root aeration and the rise of surrounding soil redox potentials (McKee 1993). Specific conditions in mangrove soils modify the partitioning of metals after their deposition and partially prevent release of these metals to the environment (Thanh-Nho et al. 2019).

The typhoon-disturbed gap site was formed by mangroves ruined after the Durian typhoon landfall (December 2006). Mangroves are naturally disturbed by tsunami, floods and cyclones (Chen et al. 2014; Hogarth 2015). Declined earlier original mangrove forests have become a source of carbon and nutrients in the rhizosphere of mangrove soils. Important in this case are activities of litter-feeding sesarmid crabs (Grapsidae) which probably depend on the availability of woody debris on the ground of the gaps. Their ecosystemengineering activities may be reduced in the gaps in comparison with those in adjacent intact mangroves (Diele et al. 2013; Filser et al. 2016). Consequently, the soil respiration $\left(\mathrm{CO}_{2}\right.$ fluxes) was significantly lower at the typhoon gap site than that at the Avicennia and Rhizophora sites. Organic matter decay in mangrove soils is a continuous process. In mangrove soils, the content of carbon in particulate form is about $2.2 \%$ (median) and varies widely from 0.1 to $40 \%$ (Kristensen et al. 2008; Alongi 2012). At our study sites, the average percentage content of particulate carbon was higher than its median and was below $3 \%$ in deeper soil layers only at the typhoon-disturbed gap site. Particulate carbon does not represent all the soil carbon.

Mangrove forests are unique in that they accumulate carbon in tree biomass, especially in belowground tree parts (roots) and the majority (75-95\%) of tree carbon stored belowground is contained in the biomass of dead rather than active live roots (Donato et al. 2011; Alongi 2012; Banerjee et al. 2020). The carbon stored in living or dead roots in mangrove soils is crucial for proper functioning of mangrove ecosystems and relates to the variability of $\mathrm{CO}_{2}$ fluxes from the soils. The expected smaller amount of live roots at the typhoon-disturbed gap site resulted in lower $\mathrm{CO}_{2}$ fluxes from the soil. Approximately half of all $\mathrm{CO}_{2}$ assimilated by intact mangrove forests are returned to the atmosphere via above- and belowground respiration (Alongi 2012). Fluxes of $\mathrm{CO}_{2}$ and $\mathrm{CH}_{4}$ from the rice field site are quite similar to fluxes from the Mangrove site as well as the fluxes of $\mathrm{CO}_{2}$ from stagnant shallow water under the Melaleuca forest canopy. This similarity between the rice field site and the Melaleuca site also explains their belonging to the same unit of acid sulphate soils (soil profile C8 at Tram Chim park (Nguyen 1993), Soil map in the Atlas delivered by the National program on integrated investigation for the Mekong River Delta, code 60-02 and 60B). Significantly different hydroperiods occurring at these sites induce a large variability in soil respiration.

In general, rice cultivation is an anthropogenic manipulation with carbon fluxes, including carbon uptake (photosynthesis), fixation (biomass, rice grain), emission (respiration) and carbon transfer to different pools (rice grain, soil) (Bhattacharyya et al. 2014). Rice varieties have different specific physiological characteristics which affect the variability of $\mathrm{CH}_{4}$ emissions (Guo and Zhou 2007). Fluxes of $\mathrm{CH}_{4}$ vary within a quite wide range, e.g., 13.1 to $492.7 \mathrm{mg} \mathrm{CH}_{4}-\mathrm{C}$ $\mathrm{m}^{-2}$ day $^{-1}$ (Cai et al. 2007). Oo et al. (2013) reported an average range of $\mathrm{CH}_{4}$ fluxes from 15.8 to $91.8 \mathrm{mg} \mathrm{CH}_{4}-\mathrm{C}$ $\mathrm{m}^{-2}$ day $^{-1}$. These fluxes are different also at different growth stages of current varieties of rice. Rice seedling have poorly developed root systems, which cannot ventilate the topsoil as effectively as a fully development root system. The root system of rice is relatively shallow and $95 \%$ of it is found at the top $0-0.2 \mathrm{~m}$ depth of the soil profile (Yoshida et al. 1982). The gas fluxes measured initially at the rice field site were low, and we expected their increase with the rice growth to a peak at 50 days (from the rice sowing in our case). According to measurements of gas flux in rice fields in south China, the methane flux from submerged paddy soil may increase a few times to its peak value within the period from transplantation of rice seedlings to their flowering stage (panicle formation or drainage of paddy field) (Khalil et al. 1998; Zhang et al. 2016). The rate of this flux is, however, variable in accordance with soil temperature, soil type and its redox condition.

\section{Conclusions}

The fluxes of $\mathrm{CH}_{4}$ and $\mathrm{CO}_{2}$ from different ecosystems of South Vietnam: intact mountain rain forest, rice field, Melaleuca forest and from different sites in mangroves (Avicennia, Rhizophora and typhoon gap) included measurements of gas fluxes from the soil and from tree stems. The gas fluxes characterized both actual and long-term 
conditions and individual specificity of these ecosystems. Based on the obtained results, we can confirm the hypothesis that high flux of $\mathrm{CH}_{4}$ occurs mainly in water-saturated soils. The highest fluxes of $\mathrm{CH}_{4}$ were recorded in the Melaleuca forest and at the mangroves sites. The fluxes from stagnant shallow water under Melaleuca canopy were accompanied by higher fluxes of $\mathrm{CH}_{4}$ from Melaleuca tree stems. However, we recorded quite a high flux of $\mathrm{CO}_{2}$ at the Avicennia and Rhizophora mangrove site. As we assumed, the prevailing gas fluxes and their ratios significantly reflect both actual and long-term hydrological conditions resulting in either anaerobic or aerobic conditions in the soil profile. We found that fluxes of both gases were higher from the soil than from the tree stems. In some cases, the difference between fluxes from the tree stems and the soil was statistically highly significant. The last hypothesis assumes possible negative flux of $\mathrm{CH}_{4}$, i.e., into the soil. We can confirm that a low negative flux (consumption) of $\mathrm{CH}_{4}$ was detected in the mountain rain forest, as we assumed. While fluxes of $\mathrm{CH}_{4}$ from tree stems varied within a very narrow range close to zero, our findings highlight quite high differences in $\mathrm{CH}_{4}$ and $\mathrm{CO}_{2}$ emissions not only between terrestrial and wetland ecosystems but also among different types of wetland ecosystems. Covering different types of (wetland) ecosystems by the in situ measurements is fundamental base for measurements at higher levels such as aerial and satellite gas fluxes observations. We think that in the future will be necessary to cover ecosystems including man-made ecosystems by in situ measurements either short-term measuring campaign or long-term continuous measurements.

Acknowledgements The authors gratefully acknowledge the financial support to their research infrastructure by the following projects: Project no. VAST.HTQT.Sec.01/16-17 of the Vietnam Academy of Science and Technology, by the National Sustainability Program I (NPU I) supported by the Ministry of Education, Youth and Sports of the Czech Republic, Grant number LO1415, and Grant number LD15040, and by the project for national infrastructure support CzeCOS/ICOS Reg.No. LM2015061. We thank to Dr. Jan Květ for the language-check of this paper.

Author contributions JD designed the study, carried out the field measurements, analysed the data and wrote the manuscript; VXN carried out the field measurements and wrote the descriptions of the measurement sites; TXL carried out the field measurements, contributed to writing the manuscript and reviewed the manuscript; MP carried out the field measurements and reviewed the manuscript.

Data availability The datasets from in situ measurements of the current study are available from the corresponding author on request.

\section{Compliance with ethical standards}

Conflict of interest The authors declare no competing financial interests.
Open Access This article is licensed under a Creative Commons Attribution 4.0 International License, which permits use, sharing, adaptation, distribution and reproduction in any medium or format, as long as you give appropriate credit to the original author(s) and the source, provide a link to the Creative Commons licence, and indicate if changes were made. The images or other third party material in this article are included in the article's Creative Commons licence, unless indicated otherwise in a credit line to the material. If material is not included in the article's Creative Commons licence and your intended use is not permitted by statutory regulation or exceeds the permitted use, you will need to obtain permission directly from the copyright holder. To view a copy of this licence, visit http://creativecommons.org/licenses/by/4.0/.

\section{References}

Acosta M, Dušek J, Chamizo S et al (2019) Autumnal fluxes of $\mathrm{CH}_{4}$ and $\mathrm{CO}_{2}$ from Mediterranean reed wetland based on eddy covariance and chamber methods. CATENA 183:104191. https ://doi.org/10.1016/j.catena.2019.104191

Alongi DM (2012) Carbon sequestration in mangrove forests. Carbon Manag 3:313-322. https://doi.org/10.4155/cmt.12.20

Banerjee K, Sahoo CK, Bal G et al (2020) High blue carbon stock in mangrove forests of Eastern India. Trop Ecol 61:150-167. https ://doi.org/10.1007/s42965-020-00072-y

Bao H, Kondo A, Kaga A et al (2008) Biogenic volatile organic compound emission potential of forests and paddy fields in the Kinki region of Japan. Environ Res 106:156-169. https://doi. org/10.1016/j.envres.2007.09.009

Bartlett KB, Crill PM, Bonassi JA et al (1990) Methane flux from the Amazon River floodplain: emissions during rising water. J Geophys Res 95:16773. https://doi.org/10.1029/JD095iD10p16773

Bekku YS, Nakatsubo T, Kume A et al (2003) Effect of warming on the temperature dependence of soil respiration rate in arctic, temperate and tropical soils. Appl Soil Ecol 22:205-210. https ://doi.org/10.1016/S0929-1393(02)00158-0

Ben-Noah I, Friedman SP (2018) Review and evaluation of root respiration and of natural and agricultural processes of soil aeration. Vadose Zone J 17:0. https://doi.org/10.2136/vzj20 17.06.0119

Best DJ, Roberts DE (1975) Algorithm AS 89: the upper tail probabilities of Spearman's rho. Appl Stat 24:377. https://doi. org/10.2307/2347111

Bhattacharyya P, Neogi S, Roy KS et al (2014) Tropical low land rice ecosystem is a net carbon sink. Agric Ecosyst Environ 189:127135. https://doi.org/10.1016/j.agee.2014.03.013

Bloom AA, Palmer PI, Fraser A et al (2010) Large-scale controls of methanogenesis inferred from methane and gravity spaceborne data. Science 327:322-325. https://doi.org/10.1126/scien ce. 1175176

Bond-Lamberty B, Thomson A (2010) A global database of soil respiration data. Biogeosciences 7:1915-1926. https://doi. org/10.5194/bg-7-1915-2010

Butenhoff CL, Khalil MAK (2002) Correction for water vapor in the measurement of atmospheric trace gases. Chemosphere 47:823-836. https://doi.org/10.1016/S0045-6535(01)00298-3

Butterbach-Bahl K, Kock M, Willibald G et al (2004) Temporal variations of fluxes of $\mathrm{NO}, \mathrm{NO}_{2}, \mathrm{~N}_{2} \mathrm{O}, \mathrm{CO}_{2}$, and $\mathrm{CH}_{4}$ in a tropical rain forest ecosystem. Glob Biogeochem Cycles. https://doi. org/10.1029/2004GB002243

Cai Z, Shan Y, Xu H (2007) Effects of nitrogen fertilization on $\mathrm{CH}_{4}$ emissions from rice fields. Soil Sci Plant Nutr 53:353-361. https ://doi.org/10.1111/j.1747-0765.2007.00153.x 
Castro MS, Steudler PA, Melillo JM et al (1995) Factors controlling atmospheric methane consumption by temperate forest soils. Glob Biogeochem Cycles 9:1-10. https://doi.org/10.1029/94GB02651

Chambers JM (2008) Software for data analysis: programming with R. Springer, New York

Chan ASK, Steudler PA, Bowden RD et al (2005) Consequences of nitrogen fertilization on soil methane consumption in a productive temperate deciduous forest. Biol Fertil Soils 41:182-189. https://doi.org/10.1007/s00374-004-0822-7

Chen H, Lu W, Yan G et al (2014) Typhoons exert significant but differential impacts on net ecosystem carbon exchange of subtropical mangrove forests in China. Biogeosciences 11:5323-5333. https://doi.org/10.5194/bg-11-5323-2014

Chimner RA (2004) Soil respiration rates of tropical peatlands in Micronesia and Hawaii. Wetlands 24:51-56. https://doi. org/10.1672/0277-5212(2004)024[0051:SRROTP]2.0.CO;2

Chowdhury TR, Herndon EM, Phelps TJ et al (2015) Stoichiometry and temperature sensitivity of methanogenesis and $\mathrm{CO}_{2}$ production from saturated polygonal tundra in Barrow, Alaska. Glob Change Biol 21:722-737. https://doi.org/10.1111/gcb.12762

Colmer TD (2003) Long-distance transport of gases in plants: a perspective on internal aeration and radial oxygen loss from roots. Plant Cell Environ 26:17-36. https://doi.org/10.104 6/j.1365-3040.2003.00846.x

Crill PM (1991) Seasonal patterns of methane uptake and carbon dioxide release by a temperate woodland soil. Glob Biogeochem Cycles 5:319-334. https://doi.org/10.1029/91GB02466

Darenova E, Pavelka M, Macalkova L (2016) Spatial heterogeneity of $\mathrm{CO}_{2}$ efflux and optimization of the number of measurement positions. Eur J Soil Biol 75:123-134. https://doi.org/10.1016/j. ejsobi.2016.05.004

Diele K, Tran Ngoc DM, Geist SJ et al (2013) Impact of typhoon disturbance on the diversity of key ecosystem engineers in a monoculture mangrove forest plantation, Can Gio Biosphere Reserve, Vietnam. Glob Planet Change 110:236-248. https://doi. org/10.1016/j.gloplacha.2012.09.003

Donato DC, Kauffman JB, Murdiyarso D et al (2011) Mangroves among the most carbon-rich forests in the tropics. Nat Geosci 4:293-297. https://doi.org/10.1038/ngeo1123

Dušek J, Acosta M, Stellner S et al (2018) Consumption of atmospheric methane by soil in a lowland broadleaf mixed forest. Plant Soil Environ 64:400-406. https://doi.org/10.17221/183/2018-PSE

FAO (1993) Mangrove for production and protection-a changing resource system: case study in Can Gio District, South Vietnam. Food and Agriculture Organization of the United Nations, Bangkok

Filser J, Faber JH, Tiunov AV et al (2016) Soil fauna: key to new carbon models. Soil 2:565-582. https://doi.org/10.5194/soil-2-565-2016

Fraser A, Palmer PI, Feng L et al (2014) Estimating regional fluxes of $\mathrm{CO}_{2}$ and $\mathrm{CH}_{4}$ using space-borne observations of $\mathrm{XCH}_{4}: \mathrm{XCO}_{2}$. Atmos Chem Phys 14:12883-12895. https://doi.org/10.5194/acp14-12883-2014

Green SM (2013) Ebullition of methane from rice paddies: the importance of furthering understanding. Plant Soil 370:31-34. https:// doi.org/10.1007/s11104-013-1790-1

Griscom BW, Adams J, Ellis PW et al (2017) Natural climate solutions. Proc Natl Acad Sci 114:11645-11650. https://doi.org/10.1073/ pnas. 1710465114

Guenther A, Zimmerman P, Wildermuth M (1994) Natural volatile organic compound emission rate estimates for US woodland landscapes. Atmos Environ 28:1197-1210. https://doi. org/10.1016/1352-2310(94)90297-6

Guo J, Zhou C (2007) Greenhouse gas emissions and mitigation measures in Chinese agroecosystems. Agric For Meteorol 142:270 277. https://doi.org/10.1016/j.agrformet.2006.03.029
Hogarth PJ (2015) The biology of mangroves and seagrasses, 3rd edn. Oxford University Press, Oxford

Hollander M, Wolfe DA, Chicken E (2014) Nonparametric statistical methods, 3rd edn. Wiley, Hoboken

Hong HTC, Avtar R, Fujii M (2019) Monitoring changes in land use and distribution of mangroves in the southeastern part of the Mekong River Delta, Vietnam. Trop Ecol 60:552-565. https:// doi.org/10.1007/s42965-020-00053-1

Inubushi K, Furukawa Y, Hadi A et al (2003) Seasonal changes of $\mathrm{CO}_{2}$, $\mathrm{CH}_{4}$ and $\mathrm{N}_{2} \mathrm{O}$ fluxes in relation to land-use change in tropical peatlands located in coastal area of South Kalimantan. Chemosphere 52:603-608. https://doi.org/10.1016/S0045-6535(03)00242-X

Ishizuka S, Tsuruta H, Murdiyarso D (2002) An intensive field study on $\mathrm{CO}_{2}, \mathrm{CH}_{4}$, and $\mathrm{N}_{2} \mathrm{O}$ emissions from soils at four land-use types in Sumatra, Indonesia: $\mathrm{CO}_{2} \mathrm{CH}_{4} \mathrm{~N}_{2} \mathrm{O}$ emissions from soils in Sumatra. Glob Biogeochem Cycles 16:22-1-22-22-1-11. https://doi. org/10.1029/2001GB001614

Itoh M, Kosugi Y, Takanashi S et al (2012) Effects of soil water status on the spatial variation of carbon dioxide, methane and nitrous oxide fluxes in tropical rain-forest soils in Peninsular Malaysia. J Trop Ecol 28:557-570. https://doi.org/10.1017/S026646741 2000569

Juszczak R, Acosta M, Olejnik J (2012) Comparison of daytime and nighttime ecosystem respiration measured by the closed chamber technique on a temperate mire in Poland. Pol J Environ Stud 21:643-658

Khalil MAK, Rasmussen RA, Shearer MJ et al (1998) Factors affecting methane emissions from rice fields. J Geophys Res Atmos 103:25219-25231. https://doi.org/10.1029/98JD01115

Kristensen E, Bouillon S, Dittmar T, Marchand C (2008) Organic carbon dynamics in mangrove ecosystems: a review. Aquat Bot 89:201-219. https://doi.org/10.1016/j.aquabot.2007.12.005

Kuhn U, Rottenberger S, Biesenthal T et al (2004) Seasonal differences in isoprene and light-dependent monoterpene emission by Amazonian tree species. Glob Change Biol 10:663-682. https:// doi.org/10.1111/j.1529-8817.2003.00771.x

Kursar TA (1989) Evaluation of soil respiration and soil $\mathrm{CO}_{2}$ concentration in a lowland moist forest in Panama. Plant Soil 113:21-29. https://doi.org/10.1007/BF02181917

Kutsch WL, Liu C, Hormann G, Herbst M (2005) Spatial heterogeneity of ecosystem carbon fluxes in a broadleaved forest in Northern Germany. Glob Change Biol 11:70-88. https://doi.org/10.111 1/j.1365-2486.2004.00884.x

Kuzyakov Y (2006) Sources of $\mathrm{CO}_{2}$ efflux from soil and review of partitioning methods. Soil Biol Biochem 38:425-448. https://doi. org/10.1016/j.soilbio.2005.08.020

Lal R, Sánchez PA, American Society of Agronomy, et al (1992) Myths and science of soils of the tropics: proceedings of an international symposium sponsored by Division A- 6 of the American Society of Agronomy, the World Association of Soil and Water Conservation, and the Soil and Water Conservation Society, in Las Vegas, Nevada, 17 Oct. 1989. Soil Science Society of America: American Society of Agronomy, Madison, USA

Lopes de Gerenyu VO, Anichkin AE, Avilov VK et al (2015) Termites as a factor of spatial differentiation of $\mathrm{CO}_{2}$ \&nbsp;fluxes from the soils of monsoon tropical forests in southern Vietnam. Eurasian Soil Sci 48:208-217. https://doi.org/10.1134/S10642293150200 88

Luyssaert S, Inglima I, Jung $\mathrm{M}$ et al (2007) $\mathrm{CO}_{2}$ balance of boreal, temperate, and tropical forests derived from a global database. Glob Change Biol 13:2509-2537. https://doi.org/10.111 1/j.1365-2486.2007.01439.x

Matson PA, Harriss RC (eds) (1995) Biogenic trace gases: measuring emissions from soil and water. Blackwell Science, Cambridge 
McKee KL (1993) Soil physicochemical patterns and mangrove species distribution-reciprocal effects? J Ecol 81:477. https://doi. org/10.2307/2261526

McMillan AMS, Goulden ML, Tyler SC (2007) Stoichiometry of $\mathrm{CH}_{4}$ and $\mathrm{CO}_{2}$ flux in a California rice paddy. $\mathrm{J}$ Geophys Res Biogeosci. 112(G1). https://doi.org/10.1029/2006JG000198

Melling L, Hatano R, Goh KJ (2005) Soil $\mathrm{CO}_{2}$ flux from three ecosystems in tropical peatland of Sarawak. Malays Tellus B 57:1-11. https://doi.org/10.1111/j.1600-0889.2005.00129.x

Mer JL, Roger P (2001) Production, oxidation, emission and consumption of methane by soils: a review. Eur J Soil Biol 37:25-50. https ://doi.org/10.1016/S1164-5563(01)01067-6

Munevar F, Wollum AG (1977) Effects of the addition of phosphorus and inorganic nitrogen on carbon and nitrogen mineralization in andepts from Colombia1. Soil Sci Soc Am J 41:540. https://doi. org/10.2136/sssaj1977.03615995004100030023x

Murguia-Flores F, Arndt S, Ganesan AL et al (2018) Soil Methanotrophy Model (MeMo v1.0): a process-based model to quantify global uptake of atmospheric methane by soil. Geosci Model Dev 11:2009-2032. https://doi.org/10.5194/gmd-11-2009-2018

Nguyen HC (1993) Geo-pedologicai study of the Mekong Delta. Southeast Aszan Stud 31:158-186

Nguyen HT (2000) Valuation of the mangrove ecosystem in Can Gio biosphere reserve, Vietnam. The Vietnam MAB National Committee, Hanoi

Nicolini G, Castaldi S, Fratini G, Valentini R (2013) A literature overview of micrometeorological $\mathrm{CH}_{4}$ and $\mathrm{N}_{2} \mathrm{O}$ flux measurements in terrestrial ecosystems. Atmos Environ 81:311-319. https://doi. org/10.1016/j.atmosenv.2013.09.030

Oo AZ, Nguyen L, Win KT et al (2013) Toposequential variation in methane emissions from double-cropping paddy rice in Northwest Vietnam. Geoderma 209-210:41-49. https://doi.org/10.1016/j. geoderma.2013.05.025

Pangala SR, Enrich-Prast A, Basso LS et al (2017) Large emissions from floodplain trees close the Amazon methane budget. Nature 552:230-234. https://doi.org/10.1038/nature24639

Parker RJ, Boesch H, McNorton J et al (2018) Evaluating year-to-year anomalies in tropical wetland methane emissions using satellite $\mathrm{CH}_{4}$ observations. Remote Sens Environ 211:261-275. https://doi. org/10.1016/j.rse.2018.02.011

Post WM, Emanuel WR, Zinke PJ, Stangenberger AG (1982) Soil carbon pools and world life zones. Nature 298:156-159. https://doi. org/10.1038/298156a0

Queiroz JS, Griswold D, Nguyen DT (2013) Vietnam Tropical Forest and Biodiversiy Assesment. Sun Mountain International and the Cadmus Group, Inc., Quito

Reay D, Smith P, van Amstel A (eds) (2010) Methane and climate change. Earthscan, London

Richardson JL, Vepraskas MJ (2001) Wetland soils: genesis, hydrology, landscapes, and classification. Lewis Publishers, Boca Raton

Segers R (1998) Methane production and methane consumption: a review of processes underlying wetland methane fluxes. Biogeochemistry $41: 23-51$
Shvaleva A, Lobo-do-Vale R, Cruz C et al (2011) Soil-atmosphere greenhouse gases $\left(\mathrm{CO}_{2}, \mathrm{CH}_{4}\right.$ and $\left.\mathrm{N}_{2} \mathrm{O}\right)$ exchange in evergreen oak woodland in southern Portugal. Plant Soil Environ 57:471-477. https://doi.org/10.17221/223/2011-PSE

Strack M, Waddington JM (2008) Spatiotemporal variability in peatland subsurface methane dynamics. J Geophys Res Biogeosci. 113(G2). https://doi.org/10.1029/2007JG000472

Tanaka K, Masumori M, Yamanoshita T, Tange T (2011) Morphological and anatomical changes of Melaleuca cajuputi under submergence. Trees 25:695-704. https://doi.org/10.1007/s0046 8-011-0547-9

Thanh-Nho N, Marchand C, Strady E et al (2019) Metals geochemistry and ecological risk assessment in a tropical mangrove (Can Gio, Vietnam). Chemosphere 219:365-382. https://doi.org/10.1016/j. chemosphere.2018.11.163

Tordoff AW, Tran QB, Nguyen DT, Le Manh H (2004) Sourcebook of Existing and Proposed Protected Areas in Vietnam, Second edition. BirdLife International-Indochina and Ministry of Agriculture and Rural Development, Hanoi, Vietnam

Tran T, Barzen J (2016) Tram Chim: Mekong River Basin (Vietnam). In: Finlayson CM, Milton GR, Prentice RC, Davidson NC (eds) The Wetland Book. Springer, Dordrecht, pp 1-7

van Bochove E, Beauchemin S, Thériault G (2002) Continuous multiple measurement of soil redox potential using platinum microelectrodes. Soil Sci Soc Am J 66:1813. https://doi.org/10.2136/ sssaj2002.1813

Wagner D (2017) Effect of varying soil water potentials on methanogenesis in aerated marshland soils. Sci Rep 7:14706. https://doi. org/10.1038/s41598-017-14980-y

Wang J, Sun J, Xia J et al (2017) Soil and vegetation carbon turnover times from tropical to boreal forests. Funct Ecol 32:71-82. https ://doi.org/10.1111/1365-2435.12914

World Meteorological Organization (WMO) (2019) WMO Greenhouse Gas Bulletin 2019:8

Xu L, Baldocchi DD, Tang J (2004) How soil moisture, rain pulses, and growth alter the response of ecosystem respiration to temperature: rain, growth, and respiration. Glob Biogeochem Cycles 18:1-10. https://doi.org/10.1029/2004GB002281

Yamanoshita T, Nuyim T, Masumori M et al (2001) Growth response of Melaleuca cajuputi to flooding in a tropical peat swamp. J For Res 6:217-219. https://doi.org/10.1007/BF02767096

Yoshida S, Bhattacharjee DP, Cabuslay GS (1982) Relationship between plant type and root growth in rice. Soil Sci Plant Nutr 28:473-482. https://doi.org/10.1080/00380768.1982.10432387

Yvon-Durocher G, Allen AP, Bastviken D et al (2014) Methane fluxes show consistent temperature dependence across microbial to ecosystem scales. Nature 507:488-491. https://doi.org/10.1038/natur e13164

Zar JH (2010) Biostatistical analysis. Prentice Hall, New Jersey

Zhang G, Yu H, Fan X et al (2016) Carbon isotope fractionation reveals distinct process of $\mathrm{CH}_{4}$ emission from different compartments of paddy ecosystem. Sci Rep. https://doi.org/10.1038/srep27065 